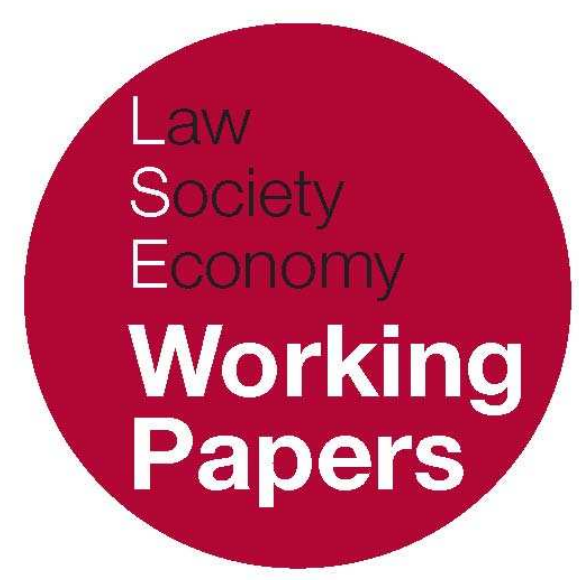

\title{
Efficiency in Private Control Sales - The Case for Mandatory Bids
}

\section{Edmund-Philipp Schuster}

LSE Law, Society and Economy Working Papers 08/2010 London School of Economics and Political Science

\author{
Law Department
}

\begin{abstract}
This paper can be downloaded without charge from LSE Law, Society and Economy Working Papers at: www.lse.ac.uk/collections/law/wps/wps.htm and the Social Sciences Research Network electronic library at: http://ssrn.com/abstract=1610259.

(C) Edmund-Philipp Schuster. Users may download and/or print one copy to facilitate their private study or for non-commercial research. Users may not engage in further distribution of this material or use it for any profit-making activities or any other form of commercial gain.
\end{abstract}




\title{
Efficiency in Private Control Sales - The Case for Mandatory Bids
}

Edmund-Philipp Schuster*

\begin{abstract}
There are two main regulatory approaches in relation to private sale-of-control transactions. The 'market rule' confers maximum freedom on a company's incumbent controller by enabling a sale of shares (hence of control over the company) to any acquirer offering an acceptable price. This concept applies to most private sale-of-control transactions in the US. On the other hand, the 'mandatory bid rule' requires a potential acquirer to offer a buy-out to all remaining shareholders once he obtains control over a company. The mandatory bid rule has its origins in the UK and now applies throughout the EU and in many other jurisdictions. Under a mandatory bid, the price offered to the remaining shareholders by the acquirer must be at least equal to the consideration received by the incumbent controller. This effectively prevents transactions with potential acquirers who are unable to offer a price acceptable to the incumbent controller to all shareholders of the company. While this warrants that no value-destroying control transfers can take place, some value-increasing takeovers are also prevented by the rule, potentially reducing the overall level of (beneficial) takeover activity. This 'chilling effect' of the mandatory bid rule, it is often argued, is too high a price to pay for the few advantages offered in exchange. This paper seeks to analyse the determinants for a reestimation of the efficiency costs entailed by the mandatory bid and market rules and argues that the efficiency advantages of the mandatory bid rule go far beyond simply deterring inefficient takeovers. The paper also emphasizes that private benefits of control - especially in
\end{abstract}

\footnotetext{
* Research Assistant, Law Department, London School of Economics and Political Science. I am indebted to David Kershaw for extremely valuable discussions and his comments on earlier drafts of this paper. I am also very grateful to Paul Davies, Peter Doralt, Leonardo Felli and the participants at the LSE Law \& Economics Forum for very helpful suggestions on particular aspects of the paper.
} 
the form of synergies - exist irrespective of the level of investor protection offered by a particular legal environment.

\section{INTRODUCTION}

Corporate takeovers can create value. Although the sources of takeover gains and, more generally, the driving forces behind the market for corporate control are still subject to much discussion in the legal and economic literature, there seems to exist a sufficient body of empirical evidence suggesting that - on aggregate $^{1}-$ takeovers do create value in practice. ${ }^{2}$

In widely-dispersed companies, control over a company can be obtained through a tender offer addressed to all target shareholders, normally preceded by negotiations with the non-owner managers, by making use of statutory merger procedures offered by the relevant jurisdiction, ${ }^{3}$ or, in some limited circumstances, through market purchases. ${ }^{4}$

Where a company is effectively controlled by one single shareholder, ${ }^{5}$ however, a potential acquirer will typically first enter into negotiations with the blockholder when seeking control over the company, as the success of the transaction will ultimately depend on this blockholder's willingness to sell his shares. ${ }^{6}$

Causes for such private control transactions, as well as problems associated with them, differ in many respects from those arising in a normal tender offer process. With ownership and control not (fully) separated, the corporate governance function of the market for corporate control plays a far lesser role, as blockholders already have sufficient incentives to effectively monitor 'their' managers. ${ }^{7}$ Furthermore, when rendering his decision about the sale of his shares,

\footnotetext{
1 ie aggregating the returns of target and bidder shareholders.

2 See, eg, G. Alexandridis, D. Petmezas and N.G. Travlos, 'Gains from Mergers and Acquisitions Around the World: New Evidence' forthcoming Financial Management Journal (at: ssrn.com/abstract=1423026). For an overview of the empirical work on this topic see, also, R. Romano, 'A Guide to Takeovers: Theory, Evidence, and Regulation' (1992) 9 Yale Journal of Regulation 119, esp 152-155.

3 Which typically require a combination of board and shareholder approval in most jurisdictions.

4 P.L. Davies and K.J. Hopt, 'Control Transactions' in R Kraakman and others (eds), The Anatomy of Corporate Law - A Comparative and Functional Approach (Oxford/New York: Oxford University Press, 2nd ed, 2009) 160. However, market purchases as a way of gaining control over a company are typically significantly complicated by various disclosure requirements.

5 Or, likewise, a coordinated group of shareholders, exercising joint control.

${ }^{6}$ Davies and Hopt, n 4 above, 161. There are, of course, situations where an acquisition can be facilitated against the will of the incumbent controller. This will be the case where the ('unsecure') blockholder controls enough voting rights to dominate the shareholders' meetings (de facto-control), without, however, holding the majority of the voting rights (de jure-control). Differences between de facto and de jure-control mainly arise due to passivity and lack of coordination of minority shareholders.

7 See, eg, P.L. Davies, E.P. Schuster, and E. van de Walle de Ghelcke, 'The Takeover Directive as a Protectionist Tool?’ (ECGI - Law Working Paper No. 141/2010, 2010) at ssrn.com/abstract=1554616, 14-15; C.G. Holderness, 'A Survey of Blockholders and Corporate Control' (2003) Economic Policy Review 51, 54-55.
} 
the blockholder is neither conflicted in the same way as a non-owner manager, ${ }^{8}$ nor as constrained by collective action problems as atomistic shareholders of a classical Berle-Means company. 9 At the same time, a separate set of problems arises in private sale-of-control transactions.

While it is a rather homogenous shareholder body who votes ${ }^{10}$ on a control transaction in widely dispersed companies, this majority decision is, in effect, substituted by the blockholder's evaluation of the offer. However, a controlling blockholder's economic position can (and often will) differ substantially from a mere aggregate of a corresponding number of non-controlling positions; this can have a decisive influence on the outcome of the control contest.

There are two fundamentally different approaches in regulating private saleof-control transactions. First, they can be treated like most other sales of private property, with the seller keeping all of the consideration paid by the acquirer, and the acquirer remaining free to decide whether or not to buy any additional shares from the remaining shareholders of the target. Alternatively, the law may impose some form of a 'sharing rule', requiring the buyer or the seller of a controlling block to let outside shareholders participate in the bargain (ie the premium, in particular) in one form or the other.

The former approach is sometimes referred to as 'market rule' or 'private negotiation rule', emphasizing its deregulatory nature; it is the concept normally applied in sale-of-control transactions in the US.

The 'sharing rule', on the other hand, is most relevant in the form of the socalled mandatory bid rule. It is the rule applicable to listed companies throughout the EEA since the adoption of the Takeover Directive; it is also applied in many other jurisdictions. ${ }^{11}$

The classical assessment of the mandatory bid rule by law and economics scholars is rather negative. It often argued that the mandatory bid rule prevents some desirable (ie efficient) transactions, and therefore creates inefficiency costs,

\footnotetext{
${ }^{8}$ From the voluminous literature see, for example, F.H. Easterbrook and D.R. Fischel, 'The Proper Role of a Target's Management in Responding to a Tender Offer' (1981) 94 Harvard Law Review 1161; J.C. Coffee, Jr, 'Market Failure and the Economic Case for a Mandatory Disclosure System' (1984) 70 Virginia Law Review 717; and J. Armour and D.A. Skeel, 'Who Writes the Rules for Hostile Takeovers, and Why?-The Peculiar Divergence of US and UK Takeover Regulation' (2007) 95 Georgetown Law Journal 1727, regarding problems linked to management discretion; see, also, Report of the High Level Group of Company Law Experts on a Modern Regulatory Framework. for Company Law in Europe (2002) 21.

${ }^{9}$ See the classical contribution by A.A. Berle and G.C. Means, The Modern Corporation and Private Property (New York: Harcourt, Brace \& World, [1932] 1968); for collective action and free-rider problems in tender offers see, eg, S.J. Grossman and O.D. Hart, 'Takeover Bids, The Free-Rider Problem, and the Theory of the Corporation' (1980) 11 The Bell Journal of Economics 42; L.A. Bebchuk, 'The Pressure to Tender: An Analysis and a Proposed Remedy' (1987) 12 Delaware Journal of Corporate Law 911, and L.A. Bebchuk, 'Takeover Bids Below the Expected Value of Minority Shares' (1989) 24 The Journal of Financial and Quantitative Analysis 171.

${ }^{10}$ Such 'voting' does not necessarily involve attending a shareholders' meeting. It can also take place in the form of shareholders 'voting with their feet', by either tendering their shares into the bidder's offer or by selling them on the market, thereby (indirectly) facilitating the acquisition by the bidder.

$11 \mathrm{eg}$, in Australia, Hong Kong, Russia, Singapore, South Africa, Switzerland, and, to some extent, in Canada (at least where the bidder pays a premium in excess of $15 \%$ over the market price) and Japan. Furthermore, the Takeover Directive is also applicable in the remaining EEA member states (Iceland, Liechtenstein and Norway).
} 
which are unlikely to be counterbalanced by the rule's (undisputed) efficiency advantages over the deregulatory approach in certain situations. ${ }^{12}$

In this paper, the question of the mandatory bid rule's efficiency is revisited. It will be argued that the mandatory bid rule offers some efficiency advantages over the market rule which are not fully taken into account in former analyses. The analysis involves substituting the question whether or not a transaction is efficient with the question bow efficient the transaction with the winning bidder is, as compared to other potential outcomes. It will be shown that, in auction-like control sales, a US-type market rule often creates suboptimal results, as it fails to facilitate control-taking by the most value creating bidder. Not taking this effect into account leads to systematic overestimation of the inefficiency costs associated with the mandatory bid rule (and similar 'sharing rules').

It will further be shown that these advantages may exist irrespective of the level of investor protection offered in a particular jurisdiction. Private benefits of control, often associated with illegal conduct by the majority shareholder, insufficient investor protection laws and inadequate enforcement, are the main drivers for differences of the two rules' performances. It will be shown that synergies play an important role in analysing the optimality of the two rules, and that the mandatory bid rule fulfils a role far beyond pure minority protection, which cannot simply be substituted by improved investor protection regulation.

The paper proceeds as follows: the first section will give a short overview of the regulatory regimes in the EU and the US, respectively. Section two will examine the efficiency implications of both rules in one bidder scenarios, mainly following prior analyses in this field. In section three, the two rules will be compared in multiple-bidder scenarios ('auctions'), identifying additional advantages of the mandatory bid rule; the fourth part concludes with a summary of the findings.

\section{PRIVATE SALES-OF-CONTROL IN THE EU AND THE US}

\section{The MANDATORY Bid Rule}

The mandatory bid rule ('MBR') has a long history. It can be traced back to the adoption of the City Code on Takeovers and Mergers ('City Code') in 1968. The City Code was, and continued to be until recently, a self-regulatory, formally non-

\footnotetext{
12 See, eg, F.H. Easterbrook and D.R. Fischel, 'Corporate Control Transactions' (1982) 91 Yale Law Journal 698; see, also, S.M. Sepe, 'Private Sale of Corporate Control: Why the European Mandatory Bid Rule is Inefficient' at: ssrn.com/abstract $=1086321$, for an overview of the relevant literature.
} 
binding body of 'soft law', administered by the Takeover Panel.13 The MBR was implemented soon after the adoption of the City Code in $1972,1^{14}$ and has remained virtually unquestioned by the Panel since then. ${ }^{15}$

First attempts to regulate takeovers on a European level date back to 1974, when the so-called 'Pennington-Report' ${ }^{16}$ was presented as part of the effort to harmonise company law throughout the European Union. The report was strongly modelled on the City Code and also suggested the obligatory introduction of a MBR on the European level. ${ }^{17}$ From then on, it took another thirty years until the Member States could finally agree on the adoption of a Takeover Directive ('TOD') in 2004.18 To end the year-long discussions, many of the most controversial points had to be 'watered-down': 19

The board-neutrality-rule, targeted at preventing defensive actions by the management without shareholder approval, and a key element of the City Code, ${ }^{20}$ was made 'optional'21 due to disagreement among member states. The breakthrough-rule, which was intended to certain render control enhancing mechanisms inoperative in the context of a takeover bid, shared the fate of the board-neutrality-rule. ${ }^{22}$

The MBR, however, made it into the final text, which can probably be explained by the fact that most Member States - in the expectation of a quick(er) adoption of the Directive - had already implemented the MBR in their domestic

${ }^{13}$ With the implementation of the Takeover Directive, the City Code has been put on a statutory footing, which, however, did not substantially change the 'soft law'-approach; see P.L. Davies, Gower \& Davies' Principles of Modern Company Law (London: Sweet \& Maxwell, 8th ed, 2008) ch 28-4, and G. Morse, 'Implementing the Thirteenth EC Directive - The End of Self-Regulation in Form Only' (2005) Journal of Business Law 403, 404. The City Code is now administered by the Code Committee due to human rights legislation (ibid).

14 Armour and Skeel, n 8 above, 1764-1765.

${ }^{15}$ N. Jennings, 'Mandatory Bids Revisited' (2005) 5 Journal of Corporate Law Studies 37, 38.

16 Report on Takeovers and other Bids (COM Doc XI/56/74).

17 R. Skog, 'The Takeover Directive-An Endless Saga?' (2002) 13 European Business and Organisation Law Review 301, 302.

${ }^{18}$ Directive 2004/25/EC of the European Parliament and of the Council of 21 April 2004 on takeover bids, O.J. L 142, 12.

${ }^{19}$ For a detailed account of the different stages of the law-making process, see, eg, V. Edwards, 'The Directive on Takeover Bids - Not Worth the Paper It's Written On?' (2004) 1 European Company and Financial Law Review 416; Skog, n 17 above; see, also, B. Clift, 'The Second Time as Farce? The EU Takeover Directive, the Clash of Capitalisms and the Hamstrung Harmonization of European (and French) Corporate Governance' (2009) 47 Journal of Common Market Studies 55, analysing the compromises made regarding the board-neutrality-rule and the breakthrough-rule.

20 But see D. Kershaw, 'The Illusion of Importance: Reconsidering the UK'S Takeover Defence Prohibition' (2007) 56 International \& Comparative Law Quarterly 267, questioning the rule's importance in the UK with a view to directors' duties.

21 'Option' is little more than an euphemism for 'abolished', as Member states obviously also had this 'option' absent any Community legislation. However, the TOD requires Member States to at least allow companies to change their articles to that effect, which, at least in theory, was not necessarily the case before the implementation. See in detail P.L. Davies, E.P. Schuster, and E. van de Walle de Ghelcke, n 7 above.

22 The optional arrangements mentioned here are further complicated through a 'reciprocity exemption'; for an overview of the rather complex system, see Davies, Schuster, and van de Walle, ibid; M. Gatti, 'Optionality Arrangements and Reciprocity in the European Takeover Directive' (2005) 6 European Business and Organisation Law Review 553; J. Rickford, 'The Emerging European Takeover Law from a British Perspective' (2004) 15 European Business Law Review 1379. 
legal systems, thereby weakening the political opposition. ${ }^{23}$ The regulation of private sale-of-control transactions can therefore be seen as largely harmonised throughout the EU.

\section{Main characteristics of the mandatory bid rule}

The MBR, as adopted in the TOD, stipulates a duty on the part of anyone who obtains effective control over a listed company, to make a general offer to all remaining shareholders of the target to acquire the residual shares. ${ }^{24}$ There is no definition of effective control in the Directive, although most countries chose to apply a threshold of $30 \%$ of the voting rights. .25

Naturally, the significance of the obligation to make such a takeover offer depends primarily on the minimum consideration to be offered to the target shareholders. The TOD - following the example of the City Code - requires Member States to determine this minimum price by reference to prior acquisitions of the bidder. The bidder has to offer to all remaining shareholders a price at least equal to the highest price he paid for shares of the target company during the last six to twelve months ${ }^{26}$ before he acquired control of the company. ${ }^{27}$

This price rule is the key-reason for the rule sometimes being called 'equal opportunity' or 'sharing-rule'. ${ }^{28}$ The bidder has to treat all shareholders equally by offering them the same price for their shares. Moreover, the offer has to be made for all outstanding shares. Where the bidder acquires a block from the controlling shareholder, all other shareholders are 'tagged-along' and receive an equal opportunity to sell their shares.

Any premium the bidder pays to the blockholder also has to be offered to the remaining shareholders. This can be seen as forcing the controlling shareholder to share 'his' 29 premium with his fellow shareholders.

To be sure, this largely simplified definition of the MBR (and, likewise, Art 5 of the Directive) fails to fully take into account other important questions, such as the definition of control or the availability of exceptions from the obligation to make an offer. ${ }^{30}$ These questions are outside the scope of the analysis provided here; it will be assumed that these rather 'technical' points can be sorted out separately.

\footnotetext{
${ }^{23}$ For an overview of pre-adoption regulation in Member States, see E. Berglöf and M.C. Burkart, 'European Takeover Regulation' (2003) 18 Economic Policy 171, 187.

${ }^{24}$ See Art 5(1).

${ }^{25}$ See Report on the Implementation of the Directive on Takeover Bids, SEC (2007) 268, 9.

26 The exact duration of this look-back period is to be determined by the Member States; the UK continues to apply a 12 -month period; CC Rule 9.5.

${ }^{27}$ See TOD, Art 5(4), which defines this price as 'equitable'.

28 L.A. Bebchuk, 'Efficient and Inefficient Sales of Corporate Control' (1994) 109 Quarterly Journal of Economics 957, 968.

${ }^{29}$ Whether the premium should 'belong' to the controller is, of course, very controversial; this paper can be seen as looking at this question in terms of efficient rule design.

30 eg, P.L. Davies, 'The Notion of Equality in Corporate Takeovers' in J. Payne (ed) Takeovers in English and German law (Oxford: Hart Publishing, 2002) 12-13.
} 
Thus, for the purposes of this paper, the MBR is assumed to (i) always be triggered where an acquirer obtains de facto-control over a company and (ii) effectively require the new controlling shareholder to offer the minority shareholders to purchase their shares at a price at least equal to what he paid to the former blockholder.

\section{Justifications of the Mandatory Bid Rule and objections}

As stated in the explanatory memorandum of the draft TOD, the Commission saw the rationale of the MBR primarily in its ability to protect minority shareholders. ${ }^{31}$

As Davies puts it, the MBR provides a 'dramatic example of [a] unilateral exit right' and prevents the acquisition of control over the whole company without acquiring (or offering to acquire) all shares. ${ }^{32}$ If this were possible, it is argued, an acquirer might be able to exploit minority shareholders by siphoning assets and engaging in self-dealing to the detriment of the minority. ${ }^{33}$

Rather than relying on ex post mechanisms to secure fair conduct of controlling shareholders towards the other investors, the exit option protects minority shareholders by offering them to leave the company at a fair price; it can therefore be seen as a substitute for, or an 'add-on' to, other minority protection devices. ${ }^{34}$ Adding to minority protection, the MBR could also lower the costs of capital, as investors do not have to fear opportunistic buyers expropriating them..$^{35}$ The possibility of 'looters' taking over control of a company, as well as further rationales of the MBR, will be addressed below in more detail.

Even if the bidder does not run the company to the detriment of the minority, it is sometimes argued that the change in the target company's business strategy by the new controller justifies a 'reinstatement of choice' by the noncontrolling shareholders, ${ }^{36}$ although this neglects the fact that even substantial changes in a company's strategy absent a change of control do not lead to a comparable exit option. ${ }^{37}$

\footnotetext{
${ }^{31}$ COM (2002) 534 final, OJ 25.3.2003 C 45/1, 7. See, also, L. Enriques, 'The Mandatory Bid Rule in the Proposed EC Takeover Directive: Harmonization As Rent-Seeking?' in G. Ferrarini, J. Winter and K.J. Hopt (eds), Reforming Company and Takeover Law in Europe (Oxford/New York: Oxford University Press, 2004) 785.

32 Davies, $\mathrm{n} 30$ above, 22.

33 eg, P. Doralt, 'Der Ökonomische Hintergrund und die Interessengegnsätze bei Übernahmeangeboten' in P. Doralt, C. Nowotny, and M. Schauer (eds), Takeover-Recht - Rechtsvergleichende Berichte, Entwurf der 13. EG-Richtlinie 1996 und Österreichischer Ministerialentwurf 1997 (Vienna: WUV Service Fachverlag, 1997) 6; Davies, ibid, 785.

34 This is the reason why the German Konzernrecht, the body of law dealing with intra-group transactions and governance, for a long time had been regarded as a potential alternative to the MBR. See, eg, Doralt, ibid 6-7.

35 This argument also lies at the heart of the 'law matters' thesis. For a recent overview see J. Black, 'Empirical Legal Studies in Financial Markets: What Have We Learned?' (2010) LSE Law, Society and Economy Working Paper Series 04-2010, at: ssrn.com/abstract=1543120.

36 See P. Lee, 'Takeover Regulation in the UK' in K.J. Hopt and E. Wymeersch (eds), European Takeovers: Law and Practice (London: Butterworths, 1992) 137.

${ }^{37}$ Jennings, $n 15$ above, 43.
} 
Probably the most common objection to the MBR is based on the "chilling effect' it has on transfers of corporate control. First, by requiring an offer to be made to all shareholders at a price equal to the per-share consideration received by the incumbent controller, an otherwise profitable transaction ${ }^{38}$ might lose its economic rationale for the bidder. ${ }^{39}$ Furthermore, as a bid is required for all shares of the company, the bidder might face financing problems, and would be required to concentrate more funds in one investment, therefore depriving him of diversification possibilities. ${ }^{40}$

Finally, it has been argued that more direct regulation might be better suitable to deal with value-decreasing takeovers, ${ }^{41}$ especially as control transactions are believed to be favourable on average. ${ }^{42}$ Clark, on the other hand, counters that a sharing requirement - equivalent to a MBR - may have the advantage of offering 'more bang for the buck' than direct regulation. ${ }^{43}$

The MBR therefore remains a controversial subject; although its capabilities to prevent inefficient takeovers are undisputed, many scholars, especially law and economics scholars, doubt the necessity of the protection it offers, given the "high cost' of the rule.

\section{THE LEgAL FrAMEWORK IN THE US}

\section{Division between Federal and State-level legislation}

Sale-of-control transactions in the US are often said to be subject to a 'market rule' ('MR'), also called a 'private negotiation rule', ${ }^{44}$ allowing the seller and the bidder to agree privately on a control transfer without an obligation to share the premium (and, hence, the transaction gains) with the remaining investors in a subsequent bid. ${ }^{45}$ Technically, such a statement is not entirely accurate, as no single national corporate law exists in the US.

Takeover law is positioned on the interface of company law and securities regulation. ${ }^{46}$ Whereas in Europe, both areas generally fall into the competence of

\footnotetext{
${ }^{38}$ Depending on the approach taken, profitable transaction, in this context, can either refer to a (Pareto efficient) transaction leaving all shareholders better off (albeit to varying extents), or to a merely overall value increasing transaction, where gains by some shareholders are partly 'subsidised' by other shareholders (which would still pass the Kaldor-Hicks efficiency test).

39 eg, Easterbrook and Fischel, n 12 above; Bebchuk, n 28 above; Enriques, n 31 above, 785. We will return to this in detail further below.

40 eg, G. Javaras, 'Equal Opportunity in the Sale of Controlling Shares: A Reply to Professor Andrews' (1965) 32 University of Chicago Law Review 420, 425-426, but see the objections by Bebchuk, n 28 above, 970-971, and R. Clark, Corporate Law (Boston: Little, Brown and Company, 1986) \$11.4, 497.

41 eg, Easterbrook and Fischel, n 12 above, 719; see, also, Jennings, n 15 above, 43.

${ }^{42}$ Enriques, $n 31$ above, 785-786.

${ }^{43}$ Clark, $\mathrm{n} 40$ above, $\$ 11.4,497-498$

44 eg, Bebchuk, n 28 above, 964.

45 Thus, the MR is probably best described as the absence of a rule, rather than a rule.

46 eg, Doralt, n 33 above, 6; Jennings, n 15 above, 38; B. Clarke, 'The Takeover Directive: Is a Little Regulation Better Than No Regulation?’ (2009) 15 European Law Journal 174, 175.
} 
Community legislation, ${ }^{47}$ the distinction between the two areas has important implications in the US. It is the (nowadays admittedly blurred) 48 dividing line between State and Federal-level legislation. Following legislative developments dating back to the "New Deal"-era, securities regulation became a matter of exclusive Federal regulation. ${ }^{49}$ Corporate law, on the other hand, remains primarily the authority of the States, which means that there are 50 different corporate laws and courts..$^{50}$

The influence this division of competences had on the development on corporate law (and particularly takeover law) in the US is subject to a longstanding academic debate ${ }^{51}$ and lies outside the scope of this paper. What is important to note, however, is the absence of a unitary US takeover regulation, comparable to the legislation passed under the TOD. Moreover, Federal law in the US neither contains a MBR, nor does it preclude States from enacting such a rule.

\section{Fiduciary duties and sharing control}

As it became clear that states were precluded by the Williams Act from taking legislative steps in the area we can broadly describe as takeover process and disclosure regulation, a second wave of State legislation arrived - the so-called State antitakeover laws. ${ }^{52}$

Rather than (directly) adding to the requirements of the Williams Act, these statutes made use of the States' competence to regulate general corporate law to give effect to their policy considerations. However, only three States (excluding Delaware) used this power to enact a rule comparable to the MBR. 53

\footnotetext{
${ }^{47}$ Although the Community's power to harmonise these areas (especially company law) is not without its limitations, European legislation now covers many areas of core company law, and the EC is now the most important legislator in securities regulation throughout Europe; see E. Wymeersch, "About Techniques of Regulating Companies in the European Union' in G. Ferrarini, J. Winter, and K.J. Hopt (eds), Reforming Company and Takeover Law in Europe (Oxford/New York: Oxford University Press, 2004) 161-169, for an overview of the law-making powers of the EC, and N. Moloney, EC Securities Regulation (Oxford: Oxford University Press, 2nd ed, 2008) 4, regarding the EC's dominant role as securities regulator throughout the Community.

48 Over the past decades, federal regulation increasingly intruded what could be seen as core company law (eg, through application of s 10b of the Securities Exchange Act 1934 and SEC Rule 10b-5); see Clark, n 40 above, 88.11.1. Similarly, R. Romano, 'The State Competition Debate in Corporate Law' (1986) 8 Cardozo Law Review 709, points to the 'invasive growth of [federal] regulation' through securities law. See, also, L.A. Bebchuk, 'Federalism and the Corporation: The Desirable Limits on State Competition in Corporate Law' (1992) 105 Harvard Law Review 1435, 1438.

49 Armour and Skeel, n 8 above, 1776-1777.

50 Romano, n 48 above; Bebchuk, n 48 above, 1438; R. Daines, 'Does Delaware Law Improve Firm Value?' (2001) 62 Journal of Financial Economics 525.

51 The debate started with W.L. Cary, 'Federalism and Corporate Law: Reflections upon Delaware' (1974) 83 Yale Law Journal 663. See L.A. Bebchuk, A. Cohen, and A. Ferrell, 'Does the Evidence Favor State Competition in Corporate Law?' (2002) 90 California Law Review 1775, for an overview of the voluminous literature, Armour and Skeel, n 8 above, for (additional) alternative explanations; see, also, M. Kahan and E. Kamar, 'The Myth of State Competition in Corporate Law' (2002) 55 Stanford Law Review 679, questioning the existence of a competition among states.

52 M. Lipton and M. Panner, 'Takeover Bids and United States Corporate Governance' in D.D. Prentice and P.R.J. Holland (eds), Contemporary Issues in Corporate Governance (Oxford: Claredon Press, 1993).

${ }^{53}$ C. Bergström, P. Högfeldt, and J. Molin, 'The Optimality of the Mandatory Bid Rule' (1997) 13 Journal of Law, Economics, \& Organization 433, 434.
} 
This, combined with the outstanding role of Delaware as a provider of corporate law to listed companies, ${ }^{54}$ makes the statement that 'US-law' does not provide for a MBR seem like a justified and practical simplification.

Turning away from State legislation, however, it is worth noting that - unlike regulation targeted specifically at the takeover process - the principle of fiduciary duties is largely homogenous throughout the US.55 In fact, there exists a longstanding debate regarding the question whether or not the incumbent controller's fiduciary duties require letting non-controlling shareholders participate in a control premium he receives when selling his shares. ${ }^{56}$

Some proponents, most prominently Andrews, ${ }^{57}$ advocated testing the scope of fiduciary duties by reference to their aim of preventing unequal distribution of profit opportunities, which, in their view, called for a duty to share the premium. Similarly, Berle and Means considered the control premium to be an asset belonging to the company, ${ }^{58}$ which would as well provide a theoretical underpinning of the sharing requirement. However, these arguments do not seem to have convinced US courts. ${ }^{59}$

As Hamilton already put it in 1985: 'It is unlikely that any American court today would reject the general proposition that controlling shareholders may obtain a premium for their shares which they need not share with other shareholders.' 60

Although the law rejects a general duty of incumbent controllers to share the premium they receive when selling their shares (and de facto-control), it does not embrace the strict deregulatory approach either. ${ }^{61}$ Instead, it defines three main exceptions to the MR. ${ }^{62}$ Where these exceptions apply, an 'equal sharing rule' is triggered and replaces the default MR.63

The first exception concerns the sale to known or suspected 'looters', ie acquirers who are likely to misappropriate corporate assets after the transaction. ${ }^{64}$

\footnotetext{
54 More than $50 \%$ of all listed US corporations are domiciled in Delaware; the closest competitor, New York, has a 'market share' of merely 5\%; Kahan and Kamar, n 51 above.

55 See, eg, J.T. Walsh, 'The Fiduciary Foundation of Corporate Law' (2002) 27 Journal of Corporate Law 333 , describing the historical development in the US.

56 An early proponent of such a 'sharing rule' is Professor Andrews (eg W.D. Andrews, 'The Stockholder's Right to Equal Opportunity in the Sale of Shares' (1965) 78 Harvard Law Review 505); in favour of the deregulatory approach, see, eg, Javaras, n 40 above, and Easterbrook and Fischel, n 12 above. See the overview given by R. Hamilton, 'Private Sale of Control Transactions: Where We Stand Today' (1985) 36 Case-Western Reserve Law Review 248.

57 Andrews, ibid 545. Andrews acknowledges, however, that the Delaware courts' readiness to allow corporate managers to respond to 'green-mailing' by offering above-market prices to buy shares, seems to embrace the opposite view (a maiore, since, in this case, even corporate funds are used unequally).

58 Berle and Means, n 9 above, 215-218; this view was explicitly rejected in Honigman v Green Giant Co., 309 F.2d 667 (8th Cir. 1962), cert. denied, 372 US 941 (1963).

${ }^{59}$ Hamilton, n 56 above, 249. Sepe, n 12 above, 17.

${ }^{60}$ Hamilton, ibid.

61 See E.R. Elhauge, 'The Triggering Function of Sale of Control Doctrine' (1992) 59 The University of Chicago Law Review 1465, 1503.

62 ibid, 1503-23. Sepe, n 12 above, 17-18.

63 Elhauge, ibid.

${ }^{64}$ eg DeBaun v First Western Bank \& Trust Co., 120 Cal.Rptr. 354 (Cal.App. 1975).
} 
This exception imposes a duty on the part of the incumbent controller to investigate the expected future conduct of an acquirer, ${ }^{65}$ where he has reason to suspect ${ }^{66}$ he might be a looter. If the suspicion persists after an investigation, he must abstain from selling his shares to this buyer, unless the other shareholders are offered an equal selling opportunity. ${ }^{67}$ In case of non-compliance with this rule, the seller will have to surrender the entire premium received and be liable for any damage caused to the remaining shareholders by the looter. ${ }^{68}$

Although the level of scrutiny in these cases goes beyond a mere application of the duty of care (the business judgment rule does not apply), ${ }^{69}$ the exception has hardly had any practical relevance, which might be due to difficulties of proving that the seller had, or should have had, the suspicion necessary to trigger the duty..$^{70}$ Notwithstanding the apparent lack of its enforcement, even this limited version of the sharing rule is subject to criticism. In the view of Easterbrook and Fischel, such a duty to investigate the buyer's motivations equals 'preventive detention of people who never have robbed banks, but have acquisitive personalities'. ${ }^{71}$

The second exception concerns so-called 'sale of office'-cases. Directors of US corporations usually have the power to appoint successors of board members resigning in between the annual shareholders' meetings, without requiring them to obtain shareholder approval. As a general rule, a director, of course, may not accept payment in exchange for transferring his position as a director to another person. ${ }^{72}$ However, where a controlling shareholder sells his interest (shares) in the company, the buyer will regularly make the transaction conditional upon his nominees being appointed as directors, which can be achieved by seriatim resignation of the old, and appointment of the new directors. Any premium received in connection with the sale of the controller's shares could therefore also be attributed to the seller's promise to appoint the buyer's nominees, therefore constituting an illegal sale-of-office.

However, at least where a majority of shares is sold, the case law allows such contracts. ${ }^{73}$ Although it is less clear which rule applies to sales de facto, but not de jure controlling blocks of shares, ${ }^{74}$ it should be borne in mind that nothing

\footnotetext{
65 ie, in relation to the corporation (and the minority shareholders).

66 The majority of cases impose such a conditional duty, triggered by circumstances that give rise to suspicion. The mere payment of a premium is not sufficient; see Elhauge, n 61 above, 1507, who advocates shifting to an affirmative duty instead.

${ }^{67}$ It is not entirely clear which level of knowledge or suspicion makes the sale of control unlawful. Knowledge and recklessness clearly suffice according to the case law, whereas it remains questionable what happens where the seller is negligent; Clark, n 40 above, $\$ 11.4 .1,479$.

68 As Elhauge, n 61 above, 1505, points out, this has 'penal' character, which can be justified by deterrence arguments.

69 ibid, 1506.

${ }^{70}$ Clark, n 40 above, $\$ 11.4 .1,480$.

${ }^{71}$ Easterbrook and Fischel, n 12 above, 719.

${ }^{72}$ Clark, n 40 above, \$11.4.1, 480.

${ }^{73}$ Essex Universal Corp. v Yates, 305 F.2d 572 (2d Cir. 1962); see also, Easterbrook and Fischel, n 12 above, 722.

${ }^{74}$ Clark, n 40 above, \$11.4.2.
} 
prevents the parties from calling a general meeting to effect the relevant appointments. Thus, the rule does not seem to constitute a major deviation from the MR.

The third exception involves what Clark calls diversions of 'collective opportunities' ${ }^{75}$ It is the exception that led to the famous decisions in Perlman v Feldmann ${ }^{76}$ and Jones v H.F. Ahmanson \& Co. ${ }^{77}$ This exception leaves the greatest leeway for discussion of a sharing requirement in US corporate law.

Although the exact meaning of the Feldmann case is subject to various interpretations, ${ }^{78}$ the practical impact appears to be rather small. Gilson and Gordon state that, although the case 'continues to amuse corporate law teachers, $[\ldots]$ by the early 1990 s, the applicable legal rule was radically different'. ${ }^{79}$ Similarly, the scope of application of the Abmanson case also seems to be rather narrow. Apart from the indifference the controllers showed to a possibly detrimental effect on the minority shareholders, Traynor C.J. explicitly refers to the lack of a business purpose of the transaction. ${ }^{80}$ Especially this latter condition will not normally be satisfied in sale-of-control transactions. Overall, the facts of both cases are rather exceptional, ${ }^{81}$ and do not seem to have led to a general reversal, or even a substantial push-back, of the market rule's general application.

Elhauge argues that by either triggering the MR or the (quasi) MBR, US doctrine utilises the optimal rule depending on the given circumstances and is therefore superior to any one of the two rules. ${ }^{82}$ Absent any reported successful 'looting cases', ${ }^{83}$ and with the other exceptions (at best) playing a minor role in US sale-of-control transactions, this seems to be an overly optimistic view. At least as far as looting cases are concerned, Clark's suggestion that the little practical significance of the rule is rooted in difficulties to prove the necessary level of 'recklessness' on the part of the seller ${ }^{84}$ appears to be more plausible.

\section{The Market Rule}

With the three exceptions described above playing a very limited role in practice, and certainly not amounting to a general sharing requirement, the rule normally applying to private sale-of-control transactions in the US is the market rule (MR). In general, the seller is thus free to transfer his controlling block to a potential

\footnotetext{
75 ibid, $\$ 11.4 .3$.

76 219 F.2d 173 (2d Cir.), cert. Denied, 349 U.S. 952 (1955).

77460 P.2d 464 (Cal. 1969).

${ }^{78}$ Clark, n 40 above, 492.

${ }^{79}$ R.J. Gilson and J.N. Gordon, 'Controlling Controlling Shareholders' (2003) 152 University of Pennsylvania Law Review 785, 793.

80460 P.2d 467; see, also, ibid, 490.

81 See Clark, n 40 above, \$11.4.3, 483-385 and 488-490, for a description.

82 Elhauge, n 61 above, 1532.

${ }^{83}$ Clark, n 40 above, \$11.4.1, 480.

84 ibid.
} 
buyer, without the requirement on his part, ${ }^{85}$ or on the part of the acquirer 86 to let the remaining shareholders participate in his gains of the transaction.

For the purposes of this paper, let us therefore define a MR as a legal framework that:

(i) allows the incumbent controller to sell his shares together with the effective control over the company at any price he is able to achieve, without having to share the proceeds with his fellow shareholders (and/or the company);

(ii) does not require the acquirer of the shares to offer to the remaining shareholders to buy the residual shares; and

(iii) allows the acquirer to voluntarily make an offer for the residual shares, at any price he thinks fit, without any reference to the price he paid to the (former) blockholder.

\section{EFFICIENT SALE-OF-CONTROL TRANSACTIONS IN ONE- BIDDER-SCENARIOS}

Having defined the two rules, this section will now proceed to the efficiency analysis of these two rules. First, an analytical framework will be presented along the lines of previous work in this field. Second, the notion of private benefits of control, central to the comparison of the two rules, will be critically examined. Thirdly, a few remarks on 'efficiency' are necessary to define the benchmark the two rules are tested against.

Using these instruments, an assessment of efficiency costs of the MBR and the MR will be provided, focusing on the question whether one particular bidder (i) should acquire control (ie in terms of social optimality), and (ii) whether he can acquire control under the relevant legal framework. The results are generally in line with the extensive prior literature on this topic. ${ }^{87}$

As no one rule is superior to the other in all circumstances, a few remarks regarding the real-life probability of the different scenarios will be provided.

\footnotetext{
85 This would be the route taken by the equal sharing school in the US.

86 ie, the MBR-solution.

${ }^{87}$ See, esp, Bebchuk, n 28 above; Bergström, Högfeldt, and Molin, n 53 above; M. Kahan, 'Sales of Corporate Control' (1993) 9 Journal of Law, Economics, \& Organization 368; S.J. Grossman and O.D. Hart, 'One Share-One Vote and the Market for Corporate Control' (1988) 20 Journal of Financial Economics 175; M.C. Burkart and F. Panunzi, 'Mandatory Bids, Squeeze-Out, Sell-Out and the Dynamics of the Tender Offer Process' in G Ferrarini, et al, n 31 above, 748-753.
} 


\section{THE ANALYTICAL FRAMEWORK}

Let $\boldsymbol{S}$ be a shareholder with de facto-control of a company, holding a proportion of $\phi$ shares of this company with $\phi[0,1]$. Let $\boldsymbol{B}$ be a potential buyer of the incumbent controller's block of shares.

Let $\boldsymbol{C F}_{\boldsymbol{S}}$ and $\boldsymbol{C F}_{\boldsymbol{B}}$ be the net present values ('NPV') of the future dividends of the company as a whole under the control of $S$ and $B$, respectively. ${ }^{88}$

Divergences between $C F_{S}$ and $C F_{B}$ can be rooted in differing abilities to manage or monitor the management of the company, differences regarding the allocation of available cash-flows between private benefits ('PBCs') ${ }^{89}$ and $\mathrm{CFs}$ (dividends), operating synergies ${ }^{90}$ and the like..$^{91}$

Let us further assume that $S$ currently receives PBCs with a NPV of $\boldsymbol{P} \boldsymbol{B}_{\boldsymbol{s}}$, whereas $B$, after taking over control of the company, would be able to extract PBCs amounting to $\boldsymbol{P B}_{\boldsymbol{B}}$, with $P B_{S}, P B_{B} \geq 0 .{ }^{92}$

Let $\triangle \boldsymbol{P} \boldsymbol{B}$ and $\triangle \boldsymbol{C F}$ be the difference between $B$ 's and $S$ 's levels of PBCs and CFs, respectively, defined as $\triangle P B=P B_{B}-P B_{S}$ and $\triangle C F=C F_{B}-C F_{S}$. The total aggregated value generated by the company for its shareholder body as a whole under $S$ 's control therefore amounts to $\boldsymbol{V}_{\boldsymbol{S}}=C F_{S}+P B_{S}$. Likewise, the total value generated by the company under B's control (ie after the transaction) would be $\boldsymbol{V}_{\boldsymbol{B}}=C F_{B}+P B_{B}$.

Before proceeding with the efficiency analysis, a closer look at the meaning of PBCs in the context of takeovers seems necessary.

\section{PRIVATE BENEFITS OF CONTROL}

It is widely recognised that a person exercising effective control over a company usually gets 'something more than other shareholders of the company. ${ }^{93}$ In other

\footnotetext{
88 In other words, CF is the basis of the share's fair value under B's and S's management, respectively; if a control transfer is not anticipated, or is not anticipated to have a value effect on the shares held by the minority shareholders, the company will have a market capitalisation of CF in an efficient market. All cash-flow rights equally shared among the shareholders are hereinafter referred to as 'CFs'.

89 PBCs are analysed immediately below.

${ }^{90}$ Bebchuk, n 28 above, 963.

${ }^{91}$ See further below.

92 Negative PBCs, ie, aggregate 'private-costs-of-control', eg, arising from reputational concerns of a parent company (Holderness, n 7 above, 55), are left out for the purposes of this analysis. Where the incumbent controller has no or negative PBCs, the efficiency performance of the MBR and the MR does not differ (although distributional differences might persist). The same is true for the marginal case, where the incumbent controller has zero PBCs; in this case, the company does have a homogenous shareholder body, and the fact that it is the blockholder who takes the selling decision should not create different outcomes irrespective of the applicable rule.

${ }^{93}$ See ibid, 54; L.A. Bebchuk and M. Kahan, 'A Framework for Analyzing Legal Policy Towards Proxy Contests' (1990) 78 California Law Review 1071, 1090; R. La Porta, et al, 'Investor Protection and Corporate Governance' (2000) 58 Journal of Financial Economics 3, 4; Grossman and Hart, n 87 above, 177; O. Ehrhardt and E. Nowak, Private Benefits and Minority Shareholder Expropriation (or What Exactly are Private Benefits of Control?) (EFA 2003 Annual Conference Paper No. 809, 2003) at ssrn.com/abstract=423506. As
} 
words, the ability to control a company has a distinct (separate) value - over and above the sum of the cash-flow rights $(\mathrm{CFs})$ attached to the shares conferring this control.

The most obvious illustration for the separability of such 'control bonuses' from cash-flow rights shared among all shareholders is a situation where the incumbent controller does not (necessarily) possess any equity holding, but still exercises effective control; this is the case for managers confronted with an unorganised, widely-dispersed and apathetic shareholder body - the managers in a Berle-Means-company. Having the possibility to run the company in their own self-interest, rather than in the investor's interest, the pure decision-making power vested in the managers has a certain value to them. ${ }^{94}$

At first glance, this might look like the attempt to equate PBCs to 'managerial agency costs'. However, managerial agency costs are the owners' losses - the profits they forgo as a consequence of sub-optimal control of their assets. When looking at PBCs, however, we do not look at the owners' losses (if any), but exclusively at the actual benefits received by the controller. Although a connection between these two values can (and often will) exist, it is important to keep the two concepts separated in the analysis.

\section{Defining Private Benefits of Control}

There is no single, generally accepted definition of PBCs. ${ }^{95}$ Grossman and Hart, for instance, define PBCs in the context of control transactions as 'benefits current management or the acquirer obtain for themselves, but that the target securityholders do not obtain. These include synergy benefits [...], the return from being able to freezeout minority shareholders [...]; perquisites of control, and in extreme cases the diversion of resources to the acquirer. ${ }^{.96}$

Similarly, Bebchuk and Kahan ${ }^{97}$ as well as Coffee $^{98}$ define them as benefits captured by the controllers, which are not shared pro rata with the other shareholders. Starting from this rather general definitions, PBCs are commonly further categorised. One common way of categorisation is to divide PBCs into pecuniary and non-pecuniary PBCs. ${ }^{99}$ Pecuniary PBCs are usually associated to some

Davies, n 30 above, 13, points out, the higher per-share value of a controlling block is also acknowledged by UK case law: Short v Treasury Commissioners [1948] A C 534, HL.

94 See, also, M.C. Jensen and W.H. Meckling, 'Theory of the Firm: Managerial Behavior, Agency Costs and Ownership Structure' (1976) 3 Journal of Financial Economics 305, 312; Grossman and Hart, ibid, 181; Kershaw, n 20 above, 268.

${ }^{95}$ See Ehrhardt and Nowak, n 93 above, for an overview of different approaches.

${ }^{96} \mathrm{n} 87$ above.

${ }^{97}$ Bebchuk and Kahan, n 93 above, 1090.

98 J.C. Coffee, Jr, 'Do Norms Matter? A Cross-Country Evaluation' (2001) 149 University of Pennsylvania Law Review 2151, 2157.

99 R.J. Gilson, 'Controlling Shareholders and Corporate Governance: Complicating the Comparative Taxonomy' (2006) 119 Harvard Law Review 1641; Ehrhardt and Nowak, n 93 above, 8; H. Demsetz and K. Lehn, 'The Structure of Corporate Ownership: Causes and Consequences' (1985) 93 Journal of Political Economy 1155, 1161-1162. 
form of 'tunneling' or 'stealing' 100 of assets, albeit not necessarily being outright illegal in all circumstances. ${ }^{101}$ Pecuniary benefits have received much attention in corporate law scholarship, to a large extent as part of the theoretical underpinning of the 'law matters'-thesis. ${ }^{102}$ Within this framework, they are often regarded as the materialisation of weak investor protection or property laws, enabling controllers of a company to misappropriate corporate assets through the employment of various mechanisms, and therefore providing him with an additional stream of income (rent).

Non-pecuniary PBCs were already described by Jensen and Meckling, ${ }^{103}$ who use the attractiveness of the secretarial staff and charitable contributions as examples. Demsetz and Lehn also recognise the existence of non-pecuniary income, related to 'the ability to deploy resources to suit one's personal preferences'. ${ }^{104}$ Examples given are the ability to influence public opinion associated to control of mass media providers and the possibility to pursue emotional goals through professional sports clubs.

However, calling such PBCs non-pecuniary is insofar misleading as these benefits are not necessarily or even typically 'free' (ie costless) to the company. ${ }^{105}$ Similarly, non-pecuniary PBCs typically have a monetary value to the controller, as there will normally exist a 'willingness to accept' associated with these benefits. This is certainly true for most of the examples typically provided for nonpecuniary PBCs, and only few situations will exist where this is not true. ${ }^{106} \mathrm{It}$ follows that most non-pecuniary PBCs come at an opportunity cost for outside shareholders. ${ }^{107}$ Where the controller receives something, which has a monetary value to the controller and (often) a monetary cost to the company (ie the minority shareholders), the 'non-pecuniary'-label seems somewhat misplaced. In most cases, the only justification for this terminology will be the form in which the controller receives the benefit. Unlike with pecuniary PBCs, non-pecuniary PBCs

\footnotetext{
100 See, eg, Gilson, ibid, 1672, describing laws against the extraction of pecuniary PBCs as a manifestation of 'thou shalt not steal'.

101 See S. Johnson, et al, ‘Tunneling' (2000) 90 American Economic Review 22, 22-23, distinguishing between 'outright theft', transfer-pricing, and the like, and value increases without assets transfers. They conclude that much of the tunneling is actually effected through the employment of legal (although 'unfair') dealings (26). See, also, A. Dyck and L. Zingales, 'Private Benefits of Control: An International Comparison' (2004) 59 Journal of Finance 537, 540.

102 eg, R. La Porta, et al, n 93 above; particularly, R. La Porta, F. Lopez-de-Silanes, A. Shleifer, and R. Vishny, 'Law and Finance' (1998) 106 Journal of Political Economy 1113. See, also, Gilson, n 99 above, for an overview.

103 n 94 above, 312 .

104 n 99 above, 1161-1162.

105 See Gilson, n 99 above, 1667-1672; A.M. Pacces, 'Control Matters: Law and Economics of Private Benefits of Control' (Rotterdam Institute of Law and Economics Working Paper No 2009/04, 2009) at ssrn.com/abstract $=1448164,7$.

106 See Gilson, ibid, 1665, describing a realistic trade-off scenario between 'psychic benefits' and an increase in monetary (family) wealth.

107 See, also, Pacces, n 105 above, 8-9.
} 
do not come in the form of money or something easily exchangeable (sold) for money. ${ }^{108}$ Clearly, these are not useful criteria for categorising PBCs.

A complementary way sometimes used to categorise PBCs is to distinguish between dissipative and non-dissipative PBCs. ${ }^{109}$ Dissipative benefits, in this context, are PBCs which are mirrored by a loss on the part of the company, eg typical asset-siphoning; these are the cases where the minority shareholders (indirectly) pay for controller's gain. ${ }^{110}$ Non-dissipative benefits, on the other hand are often equated to 'psychic benefits' derived from controlling the company. ${ }^{111}$ Just as with non-pecuniary PBCs, it is often argued that their idiosyncratic nature makes them hard to transfer. ${ }^{112}$ In fact, the two categorisations are sometimes treated as being practically equivalent or at least closely related, ${ }^{113}$ with nonpecuniary $\mathrm{PBCs}$ being equated to non-dissipative $\mathrm{PBCs}$, and pecuniary and dissipative PBCs forming the second group.

However, the division in dissipative and non-dissipative PBCs blurs the picture in so far as it implicitly tries to link PBC-extraction to outside shareholder wealth-effects. Yet, the costs for shareholders do not correspond to what is defined as PBCs. While PBCs correspond to the controller's gains, in the context used here, their willingness to accept in order to surrender them (eg the 'bribe' necessary to make him resign), the investors' corresponding losses (eg their willingness to pay for monitoring) can quite substantially differ from this value. 114

Investors' losses can be far greater (which would be the case with empirebuilding), equal (eg taking money from the company without wasting money on covering it up and still not be caught), or less (eg stealing something that is of higher value to the controller) than corresponding PBCs. Sometimes, there are no corresponding costs (eg psychic benefits purely derived from the decision-making power), or these are even 'negative' (ie benefits; this typically will be the case with synergies) for a certain level of PBCs.

The distinction between pecuniary/non-pecuniary PBCs, on the other hand, is misleading in itself. Non-pecuniary PBCs often come at a cost for the company, and they always have a value (expressible in money) to the controller. ${ }^{115}$ The only

\footnotetext{
108 See Jensen and Meckling, n 94 above, 312, stating that the controller 'will expend resources to the point where the marginal utility derived from a dollar's expenditure of the firm's resources on such items equals the marginal utility $[\ldots]$ his share of the wealth reduction'. This shows that the benefit is able of valuation in money's worth by the recipient. Also (implicitly), Dyck and Zingales, n 101 above, 540.

109 Berglöf and Burkart, n 23 above, 192; J.C. Coates IV, 'Ownership, Takeovers and EU Law: How Contestable Should EU Corporations Be?' (ECGI Law Working Paper No. 11/2003, 2003) at ssrn.com/abstract $=424720$. See, also, Bebchuk, n 28 above, 979.

$110 \mathrm{eg}$, A. Shleifer and R.W. Vishny, 'A Survey of Corporate Governance' (1997) 52 Journal of Finance 737, 759; Sepe, n 12 above, 10.

111 Bergström, Högfeldt, and Molin, n 53 above, 435; Dyck and Zingales, n 101 above, 540.

112 Ehrhardt and Nowak, n 93 above, 7.

113 ibid; see, also, Sepe, n 12 above, 10.

114 See, also, Pacces, n 105 above, 12-13, showing how even psychic benefits have a 'market value' once it comes to an acquisition decision.

115 This might have been the reason for the introduction of dissipative/non-dissipative benefits.
} 
common non-pecuniary character of such PBCs is that they are received in a form that is not easy-to-liquidate. ${ }^{116}$

\section{Synergies as private benefits}

Synergy gains exist, where a certain combination of two assets (or firms) is worth more than the aggregate value of the two assets (firms) on a stand-alone basis.117 The sources of such synergies are manifold; they can stem from operative efficiencies (economies of scope/economies of scale), better financing structures, or simply the ability to better manage the two companies. ${ }^{118}$

Just like other PBCs, synergies increase the value of the controlling shareholder stock valuation as compared with the non-controlling members of the company. It seems plausible, therefore, to include synergies into the concept of PBCs. Indeed, synergies are often explicitly mentioned as examples for PBCs, ${ }_{119}$ while others seem to assume that (pecuniary) PBCs are value reducing by definition. ${ }^{120}$

A possible objection to defining synergies as PBCs could be that synergies, unlike other forms of PBCs, typically involve some kind of sharing between the parent and the subsidiary companies. However, it can easily be shown than any allocation of synergy gains between a parent and a subsidiary (apart from allocating all to the subsidiary) will leave the parent company with a higher proportion of the gains than any other shareholder of the subsidiary, thus increasing the parent's valuation of the subsidiary's shares above the value attributed to them by the non-controlling shareholders. ${ }^{121}$

Interestingly, although often included in definitions of PBCs, synergies are often neglected subsequently, especially when it comes to empirical analyses of PBC-levels. One could almost get the impression that this may stem from the 'mislabeling' of PBCs: non-pecuniary/non-dissipative PBCs are associated with 'psychic benefits', and are therefore expected to be hard to transfer and hard to quantify. ${ }^{122}$ Pecuniary/dissipative PBCs, on the other hand, are associated with 'stealing', and are expected to be easier to pass on. ${ }^{123}$ Thus, the argument seems to go, the observation of PBCs through transactions must be confined or at least dominated by Pecuniary/dissipative PBCs, which at the same time makes them a useful proxy for good law-bad law comparisons.

\footnotetext{
116 For a different categorisation of PBCs see Pacces, n 105 above. Pacces distinguishes between 'idiosyncratic' PBCs, 'distortionary' PBCs, and 'diversionary' PBCs, and shows how these types of PBCs affect controller decision-making and ownership structure.

117 See Romano, n 2 above, 125-129, for a detailed discussion of possible synergy gains.

118 ibid.

119 eg, Grossman and Hart, n 87 above, 177; Bebchuk, n 28 above, 967; Holderness, n 7 above, 55.

120 D.K. Denis and J.J. Mcconnell, 'International Corporate Governance' (2003) 38 The Journal of Financial and Quantitative Analysis 1, 24; similarly, Dyck and Zingales, n 101 above, 539.

121 As the parent company enjoys the same CFs as other shareholders in the subsidiary plus $100 \%$ of the gains attributed to the parent.

122 Dyck and Zingales, n 101 above, 540; Ehrhardt and Nowak, n 93 above, 7.

123 Ehrhardt and Nowak, ibid, 9.
} 
However, synergies do not naturally fit into any of the two categories. ${ }^{124}$ They are created without anyone losing (the ' $1+1>2$ ' -logic), just like non-dissipative PBCs, but certainly have a clear 'pecuniary' value, which can be liquidated or even come in the form of cash - a consequence of the somewhat misleading categorisation of PBCs.

Numerous attempts have been made in order to measure the extent of PBCs enjoyed by controlling shareholders. It is inherently difficult to directly observe the level of PBCs for various reasons; most obviously, where extracting the PBCs is against the law, they necessarily are hard to observe - otherwise they would not be of any value. ${ }^{125}$

There are two general methods of estimating PBCs: The first method analyses the price differences of shares carrying the same cash-flow rights, but different voting rights. ${ }^{126}$ This allows estimating the market-value of a vote. The main drawback of this method is its 'geographical bias'; dual-class equity structures are not permitted in every country, and their use in countries where they are allowed differs widely. ${ }^{127}$

The second method estimates the levels of PBCs by analysing sale-of-control transactions. ${ }^{128}$ Comparing the share price of a company after a sale-of-control transaction with the transaction value of a sale-of-control allows one to observe the different valuations of a company's shares by the non-controlling and the controlling shareholders, respectively. ${ }^{129}$ Assuming the existence of an efficient stock market, the price differences observed can serve as an estimate for PBCs. ${ }^{130}$ A commonly accepted drawback of this method is the relative rareness of control transaction. ${ }^{131}$

It is important to note, however, that these methods measure both, synergies and other PBCs, although this is usually not properly accounted for. A prominent example can be found in the article by Dyck and Zingales. ${ }^{132}$ The assumptions made and the framework used to measure PBCs implicitly show an assumption that PBCs are the result of either undetected/unenforced illegal conduct, or are attributable to less-than-perfect investor protection rules. In fact, the study also measures synergies, as do all other studies based on observed block premia. This can be shown by the following example:

\footnotetext{
124 See, also, Pacces, n 105 above.

${ }^{125}$ See Dyck and Zingales, n 101 above, 538.

126 eg, K. Rydqvist, 'Takeover Bids and the Relative Prices of Shares that Differ in Their Voting Rights' (1996) 20 Journal of Banking \& Finance 1407; T. Nenova, 'The Value of Corporate Voting Rights and Control: A Cross-Country Analysis' (2003) 68 Journal of Financial Economics 325.

127 Dyck and Zingales, n 101 above, 543.

128 eg, ibid; see, also, M. Barclay and C.G. Holderness, 'Private Benefits from Control of Public Corporations' (1989) 25 Journal of Financial Economics 371.

${ }^{129}$ Dyck and Zingales, n 101 above, 543-544.

130 ibid.

131 ibid.

132 ibid, 538-539. See, also, Pacces, n 105 above, 6, who similarly argues that empirical studies only measure pecuniary PBCs directly extracted from shareholder wealth.
} 


\section{Example 1:}

Let us assume S-plc and B-Ltd are two companies, whose assets are comprised of nothing but a single piece of land each. The two premises are situated in an urban area and are located immediately next to each other. They formerly constituted the two halves of a single football-field. $S$, the controlling shareholder of S-plc, holds $30 \%$ of the shares, with the rest of the shares being widely-held.

B-Ltd is a fully-owned subsidiary of $B$.

The two pieces of land are currently being used as farmland and as a stockyard by S-plc and B-Ltd, respectively. S-plc has a market capitalisation of 100; this constitutes the NPV of the income generated through its farming operations.

B-Ltd lets the stockyard for a rent income with a NPV of 120.

As $\mathrm{B}$ finds out that a local football-club is interested in renting a training field, and he knows that the two pieces of land would be the club's only feasible option, he decides to buy S-plc. He anticipates a rent with a NPV of 300 for the entire football field, once the two halves can be used together, net of all costs.

Entering into the negotiations, $B$ realises that $S$, a passionate farmer, attaches a value of 20 to his ability to work on his own farmland, although he pays market prices for all products he eventually consumes and does a great job as a farmer.

$B$ assumes that he will have to divide the revenues from letting the football field 50:50 (150 each) between the two companies, as both premises have the same size.

In the example above, a transaction would certainly be value increasing and desirable. Acting rationally, $B$ and $S$ will reach an agreement: $B$ has a reservation price of 75 for S's share-block, as he will earn dividends worth $45(=150 \times 0.3)$ and his own land will appreciate by another $30 . S$ makes a profit if he sells above 50 , as his shares have a market value of $30(=100 \times 0.3)$ and he derives PBCs of 20.

Even if the deal is made at just above 50, an analysis of the PBCs using the control-transaction model ${ }^{133}$ would indicate the existence of PBCs, as the purchase price would exceed the post-transaction share price of S-plc. It is worth noting that $B$, in this example, does not extract any value from S-plc other than the better use of his own land. Furthermore, any price between 30 and 75 would be rational outcomes even if $S$ does not currently derive any PBCs. Thus, the control-

${ }^{133}$ Barclay and Holderness, n 128 above; Dyck and Zingales, n 101 above. 
transaction method of estimating PBCs includes synergies in its estimations of PBCs. Likewise, they measure all non-pecuniary or 'psychic' benefits. ${ }^{134}$

\section{Summary}

All types of PBCs, including synergies, influence the differences between the noncontrolling and the controlling shareholders' valuation of a company in the same way. Distinguishing between pecuniary and non-pecuniary PBCs is, therefore, not useful in the context of control transaction. For the purposes of this paper, the term PBC refers to any value a controller attaches to his shares (as measured by his willingness to accept), if and to the extent this value is not equally attributed to the shares by its non-controlling shareholders.

\section{SOME REMARKS ON EFFICIENCY MEASURES}

The analysis provided in this paper tries to identify the determinants for designing a rule applicable to private sales-of-control in order to create efficient results. The usual standard of desirability in corporate law is efficiency. ${ }^{135}$ This means that a rule is desirable if it maximises wealth for investors. ${ }^{136}$

The two main efficiency measures that can be used in this context are Paretoefficiency and Kaldor-Hicks efficiency. While the Pareto-test defines changes as efficient if someone profits from the change and no one is worse off, ${ }^{137}$ the Kaldor-Hicks test is satisfied whenever the aggregate gains from a change exceed the aggregate losses (potential Pareto efficient). ${ }^{138}$ This latter test is typically used when judging regulatory decisions. ${ }^{139}$

There is no clear answer as to which test is preferable in the context of corporate control transactions. ${ }^{140}$ Prior work in this field (implicitly) uses KaldorHicks efficiency, ${ }^{141}$ although Easterbrook and Fischel also consider a rule creating Pareto-efficient results. ${ }^{142}$ The question is complicated by the fact that diversified

\footnotetext{
${ }^{134}$ Dyck and Zingales, ibid, 542, argue that the 'control premium' method does not measure the value of non-pecuniary benefits. This is not entirely convincing, however. First, whenever the seller has any bargaining power $(\lambda<1$, in Dyck and Zingales' terminology), private benefits of the incumbent controller, including non-pecuniary benefits, influence the resulting price. Second, non-pecuniary private benefits, including so called 'psychic benefits', certainly influence the reservation price of the buyer of a controlling block, and are therefore reflected in the results, even where all bargaining power rests with the seller.

135 Elhauge, n 61 above, 1497.

$136 \mathrm{eg}$, B. Black and R. Kraakman, 'A Self-Enforcing Model of Corporate Law' (1996) 109 Harvard Law Review 1911, 1920. Other constituencies are protected by separate regulation; see Clark, n 40 above, $\$ 1.2 .3$.

${ }_{137}$ Or, alternatively, in its strong form, requiring that everyone wins at least something. For a detailed analysis of the different available efficiency measures, see O. Zerbe, Economic Efficiency in Law and Economics (UK: Edward Elgar Publishing, 2001).

138 ibid, 6.

139 E.R. Elhauge, 'Does Interest Group Theory Justify More Intrusive Judicial Review?' (1991) 101 Yale Law Journal 31, 53.

140 Elhauge, n 61 above, 1497.

141 eg, Bebchuk, n 28 above; Bergström, Högfeldt, and Molin, n 53 above.

142 Easterbrook and Fischel, n 12 above, 715.
} 
investors' wealth does not primarily depend on the performance of a particular asset (and, thus, the gains arising from a specific transaction). It rather is the expected aggregate impact of a given rule on the value of a (typical) portfolio of assets that counts. A rule creating efficient results (only) by the Kaldor-Hicks standard can therefore be expected to lead to Pareto-efficient results on the portfolio or investor level, as long as no systematic bias exists. ${ }^{143}$ Where all investors are equally likely to be on the winner's or loser's side with regard to each single transaction, and provided that a rule maximises aggregate welfare, everyone would be better off in the long-run with statistical certainty.

However, ensuring that no such systematic disadvantage exists is not a trivial exercise. Easterbrook and Fischel suggest that investors can avoid problems by not investing in firms dominated by non-listed companies. ${ }^{144}$ This is problematic per se, as investors following this advice would naturally increase the costs of capital for such firms, which - it could be argued - in turn would incentivise such companies to privately bargain for a sharing rule to maximise the revenue from floating the minority interest. Moreover, this argument can be extended to all controlled companies as it would always be more favourable ex ante to invest in the non-controlled parent than taking a minority position in the subsidiary unless the shares in the subsidiary sell at a discount.

The analysis in this paper uses the Kaldor-Hicks test to assess the MBR's and MR's efficiency. This approach seems favourable for two reasons. First, it is commonly accepted that a MR (at least in its 'pure form') does not necessarily create Pareto-efficient results on the single-transaction level, as a MR allows for some inefficient transfers funded by the outside shareholders' wealth. Therefore, a meaningful comparison of the two rules, going beyond a statement in favour of the Pareto-efficient MBR for 'fairness reasons' needs to consider whether one rule performs better in overall wealth creation (and, possibly, on the portfolio-level). Second, the rules analysed here are not the only available policy choices for regulating corporate control transactions. Where necessary, the superior rule in Kaldor-Hicks terms can, ex hypothesi, be adapted to yield Pareto-efficient results, as long as its outperformance does not depend on some people losing. Taking this into account, the Kaldor-Hicks performance is important, even where Pareto-efficiency is considered the preferable standard for policy choices.

143 See Easterbrook and Fischel, ibid, 714.

144 ibid. 


\title{
THE EFFICIENCY OF THE MARKET AND MANDATORY BID RULES IN ONE-BIDDER SCENARIOS
}

\author{
SELLER'S CONDITIONS FOR TRANSFERRING SHARES
}

Let us assume $S$ and $B$ enter into negotiations regarding an acquisition of $S$ 's block of shares by $B$. Naturally, $S$ will only agree to sell his shares to $B$ if he receives a full compensation for his current income stream resulting from the ownership of the shares. It follows that $S$ has a reservation price ${ }^{145}$ of, and therefore will only sell his shares for a price above:

$$
P_{\min (S)}=\phi C F_{S}+P B_{S}
$$

In other words, for the transaction to go ahead, $B$ has to offer $S$ the whole NPV of the CFs distributed to $S\left(\phi C F_{S}\right)$ plus the entire value of PBCs currently extracted by $S\left(P B_{S}\right)$. This represents the relevant willingness to accept value for the seller. It is worth emphasising that $S$ 's reservation price is the same for both, the MR and the MBR. ${ }^{146}$ As will be shown below, the price $B$ is willing to pay for $S$ 's shares, on the other hand, will differ depending on whether a MR or a MBR applies.

\section{The (in)efficiency of the Market Rule ${ }^{147}$}

Under the MR, a transfer of the controlling block will happen if, and only if, the following condition is met: ${ }^{148}$

$$
\phi C F_{B}+P B_{B}>\phi C F_{S}+P B_{S}
$$

The right-hand side of this condition simply repeats the willingness to accept condition described above. As $S$ can keep all of the consideration received for himself, a transfer will take place, if (and only if) $B$ can offer $S$ a price exceeding the current value of the shares in $S$ 's hands. ${ }^{149}$

The left-hand side of the condition represents $B$ 's reservation price (willingness-to-pay). Under a market rule, $B$ will be the owner of a proportion of shares in the target equal to $\phi$ after successfully completing the transaction. As there is no requirement to purchase additional shares of the company, the

\footnotetext{
145 The reservation price is the price below (seller)/above (buyer) which a transaction loses its economic rationale for the respective party.

146 The results do not change even where the MBR is substituted with a sharing rule imposed on the seller. In this case, the different (ie: higher) resulting reservation price of the seller is fully set-off by a lower reservation price for the bidder.

${ }_{147}$ The analysis offered here follows, in particular, the previous works of Bebchuk, n 28 above; Kahan, n 86 above; and Easterbrook and Fischel, n 12 above. Regarding Kahan's framework, an attempt has been made to simplify the transfer conditions without losing generality; see below.

148 See Kahan, n 86 above, 371. The transfer condition is equivalent to Bebchuk's proposition, although the approach taken here is based on entity values, rather than per-share values (Bebchuk, n 28 above, 965).

149 Provided that there are no rival bidders who could outbid $B$; we will return to this immediately below.
} 
transaction will be profitable to him where he pays less than the post-transaction value of $S$ 's share-block. His reservation price $\left(P_{\max (B)}\right)$ is therefore equivalent to the post-transaction value of $S$ 's shares.

$$
P_{\max (B)}=\phi C F_{B}+P B_{B}
$$

This value is formed analogous to S's decision value $\left(P_{\min }(S)\right)$ and consists of

(i) the $\mathrm{CFs}$ which $\mathrm{B}$ expects to produce as a controller $\left(\mathrm{CF}_{\mathrm{B}}\right)$, adjusted for the percentage of shares $(\phi)$, and

(ii) the PBCs which $B$ expects to extract, once he acquires control $\left(\mathrm{PB}_{\mathrm{B}}\right)$. As he is able (by definition) to keep the entire PBC-value he generates (or extracts), he will value them at their full NPV (ie without adjustment for $\phi)$.

\section{Differences between transfer and efficiency conditions}

A transfer of control is (Kaldor-Hicks) efficient if, and only if, the value generated by the company as a whole is higher post-transaction than before; in this case, any losing party could hypothetically be compensated without eroding all of the losses by the winners in the transaction. A transfer of control is therefore only efficient if the following condition is met: 150

$$
C F_{B}+P B_{B}>C F_{S}+P B_{S}
$$

In other words, the aggregate values of $\mathrm{CFs}$ and $\mathrm{PBCs}$ extracted by the controlling shareholder must be higher after the transaction than before. As can be seen above, the two conditions for the transfer of the controlling block and for the transfer's efficiency differ. Whereas the former factors in the size of $S$ 's shareholding $(\phi)$, the latter (naturally) does not.

Inefficient transfers under a Market Rule

An inefficient transfer can take place under a MR if only the transfer condition, but not the efficiency condition is met, or, more technically,

$$
\begin{aligned}
& \boldsymbol{\phi} \boldsymbol{C}_{\boldsymbol{B}}+\boldsymbol{P} \boldsymbol{B}_{\boldsymbol{B}}>\boldsymbol{\phi} \boldsymbol{C} \boldsymbol{F}_{\boldsymbol{S}}+\boldsymbol{P} \boldsymbol{B}_{\boldsymbol{S}} \text { (transfer takes place) } \\
& \text { and } \\
& \boldsymbol{C F}_{\boldsymbol{B}}+\boldsymbol{P} \boldsymbol{B}_{\boldsymbol{B}}<\boldsymbol{C} \boldsymbol{F}_{\boldsymbol{S}}+\boldsymbol{P} \boldsymbol{B}_{\boldsymbol{S}} \text { (transfer is inefficient) }
\end{aligned}
$$

The first condition simply restates the transfer condition given above, while the second is the negation of the efficiency condition. As $\phi$ represents the percentage

150 See Bebchuk, n 28 above, 963. 
of shares that are for sale, and we defined $\phi[0,1]$, it can easily be seen that where $S$ holds all shares $(\phi=1)$, the transfer condition collapses to the equivalence of the efficiency condition, meaning that only efficient transfers can happen in these cases.

Using the definitions for the two bidders' differences regarding their respective abilities to create CFs and extract PBCs from above, the conditions can also be restated as:

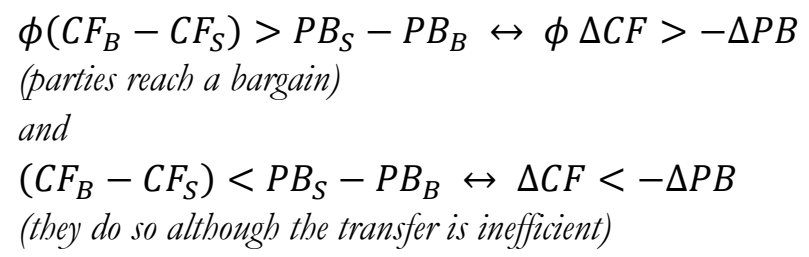

In other words, the model used here allows for the bidder, once he obtains control, to create value by increasing $C F$, available to all shareholders $(\triangle C F>0)$, and/or by extracting more PBCs than the incumbent controller $(\triangle P B>0)$.

Where the bidder is better in both, CF-generation and PBC-extraction, the transaction is necessarily efficient. For the transaction to be efficient, despite a decrease in one of the two categories, this decrease has to be fully made up for by a corresponding increase in the other category. This is expressed by the inefficiency condition above.

In the transfer condition, however, a smaller weight is put on the generation of CFs. ${ }^{151}$ This means that a decrease in cash-flow rights only has to be compensated partly by an increase in PBCs, and vice versa.

Combining the two conditions leads us to the conclusion that an inefficient transfer takes place under a MR, if, and only if

$$
\Delta C F<-\triangle P B<\phi \triangle C F
$$

Where $B$ creates higher $\mathrm{CFs}$, the transfer can therefore never take place and be inefficient at the same time. ${ }^{152}$ This can intuitively explained by the fact that $B$ and $S$ weigh CFs proportional to their shareholding, and thus no externalities can arise.

Where $B$ creates higher private cash-flows (PBCs), on the other hand, inefficient transfers are possible. Such a transfer takes place where $B$ anticipates a decrease in dividends (as compared to $S$ ), but expects to be compensated through the extraction of PBCs. While the loss of dividends is borne by all shareholders, $B$ only has to pay a part of this loss (equivalent to $\phi$ ). The bidder therefore can create negative externalities on the part of the minority shareholders. ${ }^{153}$

\footnotetext{
151 See Bergström, Högfeldt, and Molin, n 53 above, 439, for a detailed analysis of the way the two rules 'weigh' security and private benefits.

152 For positive changes in the security value $(\Delta C F), \phi \Delta C F$ can never be greater than $\Delta C F$.

153 Easterbrook and Fischel, n 12 above, 714-715, suggest a rule requiring all minority shareholders to receive at least the pre-transaction market value to alleviate this problem.
} 
Such a bidder is normally called a looter; ${ }^{154}$ bearing in mind the definition of PBCs given above, ${ }^{155}$ this is not always true. True, $B$ could be a looter. He might simply appropriate assets, which otherwise would be available for pro ratadistribution. ${ }^{156}$ With an equity holding of $50 \%$, for instance, he would use as much as $f_{1}$ to receive an extra 50p of private benefits. ${ }^{157}$ In fact, due to legal rules aimed at restricting asset-siphoning, such a 'wasteful' extraction might be necessary in order for the siphoning not being spotted by the other investors and the regulators. ${ }^{158}$

However, equalising a post-transaction decrease of the share price with 'stealing' implicitly assumes that the minority shareholders have property rights regarding the level of CFs generated under $S$ 's control. This is certainly true (at least indirectly) in respect of the assets of the company, as almost every country in the world will have rules prohibiting the appropriation without compensation of the company's property by the controller. ${ }^{159}$ As far as synergies are concerned, however, this must not always be true.

\section{Example 2:}

$\mathrm{X}$-Air plc, an airline-operator, runs an airport-taxi business through a listed subsidiary, X-Taxi plc, the shares of which are held by X-Air plc (51\%) and dispersed shareholders (49\%). Under a licensing agreement with X-Air, $\mathrm{X}$-Taxi uses the 'X-Air' brand name, and customers often choose X-Taxi because of X's reputation (despite above-market prices). The consideration for using the brand name amounts to less than the additional revenues generated through the reputation effect.

Upon expiry of the licensing agreement, X-Air decides to sell-off X-Taxi, eg because X-Air's benefits (eg the increased customer loyalty) have substantially decreased in recent time.

$\mathrm{X}$-Air's shares in X-Taxi are then sold to Y-Oil, a company running gas stations. Despite the anticipated lower future profits of X-Taxi (due to the loss of X-Air's brand name), Y-Oil expects a lower volatility of its petrol sales, as it supplies X-Taxi with petrol (at market prices). As demand becomes more predictable for Y-Oil, it can sell one of its current fuel-storages. The cost savings amount to $75 \%$ of $\mathrm{X}$-Taxi's lost profit.

It can hardly be argued that there is any illicit or unfairly prejudicial conduct involved in the above example by either of the involved parties. Nevertheless,

\footnotetext{
154 Jennings, n 15 above, 42.

155 See text to $n 117$ above.

156 Johnson, et al, n 101 above.

157 Jensen and Meckling, $\mathrm{n} 94$ above, 312.

${ }^{158}$ La Porta, et al, n 93 above, 6, using the costs for setting-up intermediary companies as an example.

159 Johnson, et al, n 101 above, 22-23.
} 
following the transfer, the share price of X-Taxi will decline without any of the contracting parties taking the entire lost value into consideration when making the investment decision. The example shows how the loss of synergies can operate as an externality against which shareholders are not protected. Claims that inefficient sales-of-control under a MR can (fully) be prevented by more targeted rules aimed at investor protection ${ }^{160}$ typically neglect this part of the problem. This also means that the fiduciary obligation to share profits from a sale-of-control to "looters"161 could not even prevent all inefficient transactions, where their enforcement works perfectly.

Prevented efficient transfers under a Market Rule

A second source of inefficiencies arises, where efficient (desirable) transactions are prevented from happening under a specific rule. Analogous to above, the market rule prevents efficient transactions if, and only if

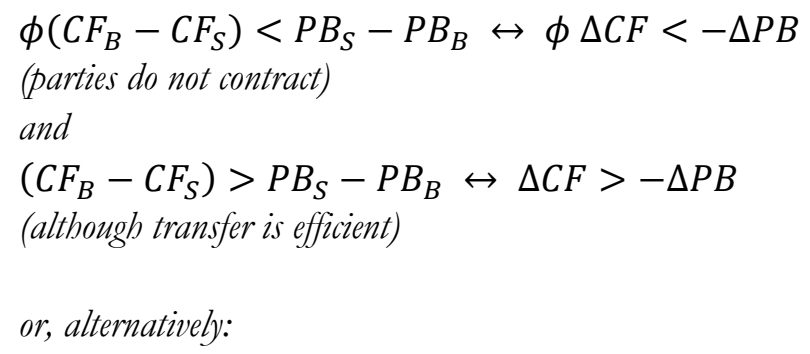

$$
\phi \triangle C F<-\triangle P B<\triangle C F
$$

Two things can be derived from this statement of the inefficiency condition. First, the MR allows all transfers, where CFs and PBCs increase as a consequence of the control shift. ${ }^{162}$ Second, efficient transfers will only be blocked under a MR, where $B$ extracts less PBCs than $S .163$

Less technical, a transfer of control will not happen, where the higher future dividends after the transaction do 'compensate' for the losses in PBC-extraction on an entity-basis. However, the bidder cannot fully reap these profits, as he owns only a portion of $\phi<1$ of the shares. The remaining shareholders are, from $B$ 's viewpoint, a 'profit leak', making the transaction unprofitable.

Turning back to Example 1 above, this could be the case where $B$ uses currently gets 145 from using his land, and therefore experiences a smaller synergy (PBC) through the transaction. Although the transaction would still be efficient $(\triangle C F=50 ;-20 \leq \triangle P B<-15)$, a transfer could not happen, as $B$ offers less than $50(5+150 \times 0.3)$, while $S$ needs to be offered at least 50 .

As Bebchuk points out, $S$ will not normally be able to overcome this problem by buying out the remaining shareholders based on the present securities value and

\footnotetext{
160 eg, Jennings, n 15 above, 43.

161 See text to $\mathrm{n} 64$ above.

162 With $\triangle C F, \triangle P B>0, \phi \Delta C F<-\triangle P B$ cannot be true.

${ }^{163}$ For $\Delta C F<0, \phi \Delta C F<\Delta C F$ cannot be true.
} 
consequently sell the $100 \%$-stake to $B$, primarily for free-rider problems. ${ }^{164}$ In the absence of a freeze-out rule allowing $S$ or $B$ to force the shareholders to sell their shares at a value below the post-transaction share value, such transactions are therefore prevented by the MR.

THE (IN)EFFICIENCY OF THE MANDATORY BID Rule

As stated above, in the presence of a MBR, $S$ will sell his shares under exactly the same conditions as in the presence of a MR. Differences exist, however, regarding $B$ 's willingness-to-pay. Confronted with a legal obligation to offer all remaining shareholders the same price as $S$, the maximum price $B$ is ready to pay needs to factor in the expected costs for the mandatory bid.

Under a MBR, a sale-of-control happens if, and only if

$$
\phi P B_{B}+\phi C F_{B}>P B_{S}+\phi C F_{S} \leftrightarrow \boldsymbol{P B}_{\boldsymbol{B}}+\boldsymbol{C} \boldsymbol{F}_{\boldsymbol{B}}>\frac{\boldsymbol{P} \boldsymbol{B}_{S}}{\boldsymbol{\phi}}+\boldsymbol{C} \boldsymbol{F}_{\boldsymbol{S}}
$$

The right-hand side of the first inequality restates the transfer condition for $S$. The left-hand side represents the reservation price of $B$. It can be seen that, unlike in an MR-environment, $B$ cannot pay for $S$ 's shares using his entire $C F$-potential. Instead, the maximum price he can offer to $S$ reflects his inherent sharing obligation, by paying $S$ a maximum of his share $(\phi)$ of the company's posttransaction value. ${ }^{165}$

\section{No inefficient transfers under the Mandatory Bid Rule}

It can easily be shown, that inefficient control transfers cannot happen under a MBR. This can be intuitively derived from the fact that the per-share value for $S$ always at least equals the per-share values of the remaining shareholders. ${ }^{166}$ As $B$ has to offer the same price he paid $S$ to all remaining shareholders, the rational decision of $B$ leads to all remaining shareholders also to be offered a price above their current share-values:

\footnotetext{
164 Bebchuk, n 28 above, 966-967; see, also, Grossman and Hart, n 8 above; L.A. Bebchuk and O.D. Hart, 'Takeover Bids versus Proxy Fights in Contests for Corporate Control' Harvard Law and Economics Discussion Paper No 336 at: ssrn.com/abstract $=290584$.

${ }^{165}$ Kahan, n 86 above, 371 , splits the transfer requirement according to the other shareholders' expected acceptance of the mandatory bid (Proposition 3). It seems, however, that such split is unnecessary, as the maximum price $B$ is willing to pay always at least equals the post-transaction share price (for $\mathrm{PB}_{\mathrm{B}}>0$ ). It follows that, whenever a transfer is possible under the MBR, $B$ can make the other shareholders accept his offer without turning an otherwise profitable transaction unprofitable. See, also, Bebchuk, ibid, 973. 166 ie, $\mathrm{PB}_{\mathrm{B}} \geq 0$.
} 


$$
\begin{aligned}
& P B_{B}+C F_{B}<P B_{S}+C F_{S} \text { (inefficiency), and } \\
& P B_{B}+C F_{B}>\frac{P B_{S}}{\phi}+C F_{S} \text { (transfer), } \\
& \text { we derive: } \frac{P B_{S}}{\phi}+C F_{S}<P B_{S}+C F_{S} \leftrightarrow \frac{P B_{S}}{\phi}<\boldsymbol{P} \boldsymbol{B}_{S}
\end{aligned}
$$

This condition for inefficient transfers can never be met, for any $\phi \leq 1, P B s>0$.

\section{The 'private benefits burdle'}

Whereas inefficient transfers cannot proceed under a MBR, some efficient transfers are blocked. Efficient transfers are prevented in an MBR-environment if, and only if,

$$
\begin{aligned}
& P B_{B}+C F_{B}>P B_{S}+C F_{S} \leftrightarrow-\boldsymbol{\Delta P} \boldsymbol{B}<\Delta \boldsymbol{C} \boldsymbol{F} \text { (transfer would be efficient), } \\
& \text { and } \\
& P B_{B}+C F_{B}<\frac{P B_{S}}{\phi}+C F_{S} \leftrightarrow \Delta \boldsymbol{C} \boldsymbol{F}<\frac{\boldsymbol{P} \boldsymbol{B}_{S}}{\boldsymbol{\phi}}-\boldsymbol{P} \boldsymbol{B}_{\boldsymbol{B}} \text { (transfer does not happen) }
\end{aligned}
$$

It follows that efficient transfers are blocked by the MBR, if, and only if, ${ }^{167}$

$$
-\triangle P B<\Delta C F<\frac{P B_{S}}{\phi}-P B_{B}
$$

In other words, for (efficient) transfers to happen under a MBR, $B$ needs to create efficiency gains that allow him to buy out all shareholders at a price equal to what he pays $S$. This requires him to pay multiple times for $S$ 's PBCs, expressed by $\frac{\boldsymbol{P} \boldsymbol{B}_{S}}{\boldsymbol{\phi}}$. It is this multiplying effect that lets the MBR prevent more efficient takeovers than the MR. The MBR therefore compensates the minority shareholders for something they do not currently enjoy (PBCs).

Turning back to Example 1, this would be the case where B currently earns more than 133.3 with his piece of land, thus shrinking his PBCs to a value lesser than 16.7; note that this requires more PBCs than the equivalent problem with the MR (5). Thus, a MBR prevents more efficient transfers than the MR. ${ }^{168}$

\section{AgGREGATE COSTS OF THE RULES IN A ONE-BIDDER SCENARIO}

From the description above it can be seen that the MBR prevents more inefficient control transfers than the MR, while the MR allows some inefficient transfers to happen. ${ }^{169}$ In order to calculate the aggregate efficiency costs associated with the two rules, one would need to observe the likelihood of the relevant situations.

\footnotetext{
${ }^{167}$ See Bebchuk, n 28 above, 971 (Corollary 5), and Kahan, n 86 above, 373 (Proposition 6). 168 Bebchuk, ibid, 971.

169 See above; this is in line with ibid, 960; Bergström, Högfeldt, and Molin, n 53 above; Burkart and Panunzi, $n 87$ above, 752 .
} 
To this end, Bebchuk tries to estimate the probabilities of efficient bidders not being able to take control over the target under both rules, and an inefficient bidder succeeding under a MR. ${ }^{170}$ Bebchuk's results depend on the distribution of PBCs and CFs among potential bidders and point to an advantage of the MR under most of the realistic assumptions he makes.

It has to be taken into account, however, that this statistical analysis implicitly simulates offers by random potential bidders - one at a time - and aggregates the efficiency results of these hypothetical transactions by 'counting' the successful and unsuccessful bidders under each rule, depending on the efficiency or inefficiency of them taking control. Doing so, Bebchuks's estimate effectively gives an idea of the proportion of potential bidders meeting the efficiency and the transfer requirements under the MR and the MBR.

Although this is a useful starting point to identify the conditions under which one of the two rules is superior, it has to be borne in mind that this 'binary' approach (ie counting whether a bidder is successful or not) does not provide a complete estimate of the real inefficiency costs entailed by the two rules. The probability of no bidder meeting the transfer requirements of the MBR, however, depends inter alia on the number of interested buyers for a specific company and the variance between these bidders. ${ }^{171}$

As will be shown below, the MBR has a positive screening function among all efficient bidders. Thus it is suggested here that in circumstances where some bidders can take control over the target under both rules, the MBR has additional advantages over the MR that need to be taken into account.

Another argument against the MBR's merits is based on the notion that PBClevels between two bidders are likely to be very similar, as they depend on the legal rules applicable to the target company. ${ }^{172}$ By also accounting for potential synergies, the analysis presented here takes away some of the force of this argument, because PBCs are not a mere function of 'good' or 'bad' law.

Moreover, Dyck and Zingales find that the level of PBCs also depends on the origin of the bidder, ${ }^{173}$ potentially giving bidders from certain countries a systematic advantage in PBC-levels (but most likely not in CF-levels). Finally, the claim that the MBR leads to higher ownership concentration as incumbent controllers fear to be deprived of their PBCs by a hostile bidder, thus reducing contestability of control, ${ }^{174}$ seems unconvincing. Apart from the unlikeliness of hostile bids in block-holder companies, ${ }^{175}$ consolidation of control actually increases

\footnotetext{
170 Bebchuk, n 28 above, 974-981.

171 ibid.

172 eg, Bergström, Högfeldt, and Molin, n 53 above, 447.

173 Dyck and Zingales, n 101 above, 563.

174 Sepe, n 12 above, 29.

175 eg, Berglöf and Burkart, n 23 above, 176-177, who show that in the mainly blockholder-dominated Continental European countries hostile takeovers are very rare.
} 
contestability of control under both rules, as a larger proportion of PBCs is internalised by a controller holding a large equity stake. ${ }^{176}$

It remains to be said that estimating the efficiency costs of the two rules is a difficult task, as many different factors play a role. More empirical work needs to be done in order to correctly assess the likelihood of one rule's outperformance.

\section{PRIVATE CONTROL AUCTIONS}

The analysis provided so far only deals with scenarios where one potential bidder, $B$, enters into negotiations with $S$ to buy his controlling block. It is unlikely however, that $S$ simply engage in exclusive negotiations with $B$. A controlling block in a listed company typically represents a significant investment; $S$ will therefore rationally use considerable resources in order to find the 'right' acquirer for his shares.

This search for the bidder will often be carried out through an auction, ${ }^{177}$ or an informal procedure expected to lead to the same result - identifying the bidder with the highest willingness-to-pay. ${ }^{178}$ As non-controlling shareholders of the target will not normally have a say in the procedure, the 'auction' will be decided based solely on the purchase price for B's shares. This section examines the MR and the MBR in such 'control auctions'.

\section{ANALYTICAL FRAMEWORK}

Building on the framework provided above, let us assume that $B$ is not the only bidder in the auction. There exist two bidders $\left(B_{1} ; B_{2}\right),{ }^{179}$ both interested in buying $S$ 's shares. The bidders differ in both $C F_{B 1 ; B 2}$ and $P B_{B 1 ; B 2}$.

Let us further assume that $S$ will choose to sell to the bidder offering him the highest price for $S$ 's control block, if he exceeds $S$ 's reservation price.

\section{SECOND-BEST OUTCOMES IN PRIVATE AUCTIONS UNDER THE MARKET RULE}

Under a MR, $S$ will sell his shares under the same transfer condition as stated before. Accordingly, a bidder $\left(B_{1 ; 2}\right)$ will be able to purchase the controlling block, if, and only if,

\footnotetext{
176 See P.L. Davies, E.P. Schuster, and E. van de Walle de Ghelcke, n 7 above, 14-15.

177 See J. Bulow and P. Klemperer, 'Why Do Sellers (Usually) Prefer Auctions?' (2009) 99 American Economic Review 1544, analysing in detail the optimal design of a selling procedure to maximise sellers' revenue. See, also, A.L. Boone and H.J. Mulherin, 'Do Auctions Induce a Winner's Curse? New Evidence From the Corporate Takeover Market' (2008) 89 Journal of Financial Economics 1; A.L. Boone and H.J. Mulherin, 'How are Firms Sold?' (2007) 62 Journal of Finance 847-875..

178 Provided that the offers exceed $B$ 's reservation value.

179 The same applies to any auction with $n$ bidders.
} 
and

$$
\phi C F_{B 1 ; 2}+P B_{B 1 ; 2}>\phi C F_{S}+P B_{S}
$$

$$
\phi C F_{B 1 ; 2}+P B_{B 1 ; 2}>\phi C F_{B 2 ; 1}+P B_{B 2 ; 1}
$$

The second condition simply requires one bidder's price to be higher than the other's. Analogous to the inefficiencies associated to the MR in one-bidder scenarios, inefficiencies can result where the winning bidder is not, at the same time, the most efficient bidder.

To examine whether the highest bid is placed by the more efficient bidder, one has to examine the two price functions and the efficiency condition. Inefficiency costs arise, if, and only if:

$$
\begin{aligned}
& \phi C F_{B 1}+P B_{B 1}<\phi C F_{B 2}+P B_{B 2}\left(B_{1}\right. \text { loses the auction) } \\
& \text { and } \\
& C F_{B 1}+P B_{B 1}>C F_{B 2}+P B_{B 2}\left(B_{1}\right. \text { creates more value) }
\end{aligned}
$$

If we compare the two bidders using $\boldsymbol{\sigma} \boldsymbol{C F}\left(C F_{B 1}-C F_{B 2}\right)$ and $\boldsymbol{\sigma} \boldsymbol{P B}\left(P B_{B 2}-\right.$ $\left.P B_{B 1}\right)$ as the differences in value creation between $B_{1}$ and $B_{2}$, regarding PBCs and future dividends, respectively, we derive

$$
\phi(\sigma C F)<-\sigma P B<\sigma C F
$$

As above, inefficiencies are therefore created, where the more efficient bidder creates a larger proportion of his gains in terms of security values, rather than PBCs. In other words, for every $£$ of $\mathrm{PBC}$ s extracted by the less efficient, which is not equally extracted by the more efficient bidder, the latter has to earn the higher value of $\frac{E}{\phi}$ in additional security benefits.

Turning back to Example 1 from above, let us assume $B_{1}$ (ie $B$, controlling BLtd) competes with $B 2$ over S's control block. Let us further assume that $B_{2}$ (who wants to use the land as a landfill) can extract PBCs of 70 by running the company (eg the cost-savings from disposing his industrial waste closer to his factory), and that he intends to pay a rent to B-plc, which equals the revenues of the farming business. The auction situation can be illustrated as follows:

\begin{tabular}{|c|c|c|c|c|}
\hline $\boldsymbol{\phi}=\mathbf{3 0} \%$ & CF & PB & $\begin{array}{c}\text { efficiency } \\
\text { value }\end{array}$ & Price \\
\hline$S$ & 100 & 20 & 120 & $\begin{array}{c}P_{\min }=50 \\
(100 \times 0,3)+20\end{array}$ \\
\hline$B_{1}$ & 150 & 30 & 180 & $\begin{array}{c}P_{\max }=75 \\
(150 \times 0,3)+30\end{array}$ \\
\hline$B_{2}$ & 100 & 70 & 170 & $\begin{array}{c}P_{\max }=100 \\
(100 \times 0,3)+70\end{array}$ \\
\hline
\end{tabular}


Despite $B_{1}$ creating a higher value overall, $B_{2}$ will still be able to outbid him, due to his PBC-advantage. The MR, therefore, creates second-best results in bidder auctions, where differences exist between the participants regarding their PBClevels, and these cannot be counterbalanced by higher CFs.

Such situations create additional efficiency costs of the MR: whenever a controlling block is for sale, the MR skews the competition towards the bidder creating a larger proportion of the gains in PBCs, rather than letting the most efficient bidder win; among two parties creating the same overall value surplus, a MR will always lead to the bidder with the higher $\mathrm{PBC}$-value winning the auction. ${ }^{180}$ It can also be shown that the parties involved $\left(\mathrm{S} ; \mathrm{B}_{1} ; \mathrm{B}_{2}\right)$ cannot resolve this 'dilemma' through bargaining amongst themselves. ${ }^{181}$

Note that in this example, both bidders actually create values; this is not necessarily the case. As described above, the MR also allows some inefficient transactions to happen. In such situations, even an inefficient bidder can outbid a value-creating one.

\section{CONTROL AUCTIONS UNDER A MANDATORY Bid Rule}

Under a MBR, the same problems do not exist. This logically follows from the MBR's ability to block all inefficient transactions. $B_{2}$, being the less efficient bidder, could never purchase the block from $B_{1}$. It follows that $B_{1}$ must have a higher reservation price than $\mathrm{B}_{2}$ under a MBR.

More formally, under a MBR, a less value-creating bidder will win the auction if, and only if,

$$
\begin{aligned}
& \begin{array}{l}
\phi C F_{B 1}+\phi P B_{B 1}<\phi C F_{B 2}+\phi P B_{B 2} \leftrightarrow \boldsymbol{C F}_{\boldsymbol{B} 1}+\boldsymbol{P} \boldsymbol{B}_{\boldsymbol{B} 1}<\boldsymbol{C} \boldsymbol{F}_{\boldsymbol{B} 2}+\boldsymbol{P} \boldsymbol{B}_{\boldsymbol{B} 2} \\
\text { and }
\end{array} \\
& \qquad \boldsymbol{C} \boldsymbol{F}_{\boldsymbol{B} 1}+\boldsymbol{P} \boldsymbol{B}_{\boldsymbol{B} 1}>\boldsymbol{C} \boldsymbol{F}_{\boldsymbol{B} 2}+\boldsymbol{P} \boldsymbol{B}_{\boldsymbol{B} 2}
\end{aligned}
$$

These reverse conditions can self-evidently never be fulfilled.

In other words, the MBR requires every bidder to weigh PBCs and cashflow rights equally, as does the efficiency condition. Between any two bidders, it is therefore always the most value-creating who wins the auction, irrespective of how the gains are distributed between PBCs and CFs. Turning back to Example 1, as modified above, ${ }^{182}$ the same 'bidder contest' would look as follows:

\footnotetext{
180 A similar conclusion drawn by Bergström, Högfeldt, and Molin, n 53 above, 440, for tender offers, based on Grossman and Hart, $\mathrm{n} 87$ above, is addressed further below.

181 We will return to this point further below.

182 See text to $n 133$ above.
} 
$08 / 2010$

\begin{tabular}{|c|c|c|c|c|}
\hline $\boldsymbol{\phi}=\mathbf{3 0 \%}$ & CF & PB & $\begin{array}{c}\text { efficiency } \\
\text { value }\end{array}$ & Price MBR \\
\hline$S$ & 100 & 20 & 120 & $\begin{array}{c}P_{\min }=50 \\
(100 \times 0,3)+20\end{array}$ \\
\hline$B_{1}$ & 150 & 30 & 180 & $\begin{array}{c}P_{\max }=54 \\
\phi \times(150+30)\end{array}$ \\
\hline$B_{2}$ & 100 & 70 & 170 & $\begin{array}{c}P_{\max }=51 \\
\phi \times(100+70)\end{array}$ \\
\hline
\end{tabular}

As stated above, the equal weight given to CFs and PBCs leads to the most efficient bidder always winning the auction.

\section{Conditions for the MBR's outperformance}

To be sure, the inefficiencies attached to the MBR still remain the same. In onebidder, as well as in multi-bidder scenarios, it is possible that no bidder can jump over the 'PBC-hurdle' under a MBR. Although this is also true for the MR, the extent to which this applies is greater in an MBR-environment. ${ }^{183}$ A pre-condition for the MBR's outperformance therefore is a situation where at least one bidder creates enough gains to allow a transfer under the MBR. In addition, where the differences between the bidders are sufficiently large $(\sigma P B<\phi[\sigma C F])$, the most efficient bidder will win the auction under any of the two rules.

The MBR therefore performs better in control auctions, than the MR, if, and only if,

$$
\sigma P B>\phi \sigma C F \text { and } \phi \triangle C F<-\triangle P B<\triangle C F
$$

These conditions represent the skewness of the MR towards the bidder with the highest PBCs. Adding this feature to the efficiency analysis of the MBR also means that the mere fact of aggregate abnormal returns following control transfers ${ }^{184}$ cannot be equalled to a better aggregate performance of the MR. ${ }^{185}$ Transfers being efficient in aggregate does not per se mean that the MR is superior to the MBR, as forgone efficiency losses are not taken into account by that view.

Furthermore, the analysis presented here, showing a better performance of the MBR in multi-bidder scenarios is somewhat contrary to Bebchuk's results. ${ }^{186}$ The differences can be explained as follows: Bebchuk assumes an indefinite number of rounds, with random bidders taking over control of the company. ${ }^{187}$ In such a situation, the MBR can, indeed, underperform, if a high-PBCs/low-CF bidder acquires control and no subsequent bidder meets the transfer conditions after that. However, the view presented here differs in so far as - maybe more realistically - the person acquiring control already needs to outbid his competitors

\footnotetext{
183 See text to n 167 above.

184 Holderness, $\mathrm{n} 7$ above, 54-55.

185 This conclusion is drawn, eg, by Berglöf and Burkart, n 23 above, 198.

186 Bebchuk, n 28 above, 980, testing multiple/infinite rounds of control changes.

187 ibid.
} 
in the 'first round'. Assuming that not random, but the most suitable, bidders will participate in the auction, the MBR leads to the first-best result in this one auction.

\section{Distribution of transaction gains}

The outperformance of the MBR described above is dependent on the levels of PBCs created by the two bidders. It has been argued that a MBR, while indirectly preventing asset-siphoning to some extent, a more targeted approach, directly addressing 'looting' would be preferable. ${ }^{188}$ As showed above, inefficiency costs of the MR can exist even in the absence of any illegal or immoral 'looting', as the relevant PBC-levels are to be determined taking into account synergies by the parties involved.

Even where investor protection laws actually deter 'looting' effectively, and no illegal PBCs can be extracted, the described advantages of the MBR would still persist in most cases. Where the takeover gains of the different potential bidders stem from different sources, ie one bidder expects to create disproportionally more value through the extraction of PBCs, while another bidder's gains stem from increasing shared cash-flows to a larger extent, the MBR - by taking an equal weight on both types of gains - favours the best bidder, unless company law would demand that synergy gains are always assigned entirely to the target company. In this case, the synergies from a transaction only benefit the target company, so they no longer constitute PBCs. Thus, they would not influence the acquirer's and seller's behaviour in the way described above, and the differences between the two rules would disappear.

Even in case the gains of all bidders are distributed identically between PBCs and $\mathrm{CFs}^{189}$ - which does not seem to be a very realistic assumption per se - the MBR's advantages would still exist unless company law provides for a fixed distribution key for synergy gains, determining the proportion of the gain to be assigned to the target company and the parent company, respectively.

Both qualifications, however, are certainly not true. There exists no agreement among lawyers (nor among economists) giving a general answer on how to divide gains from transactions between a parent and a subsidiary company, ${ }^{190}$ and few (or no one) would argue that the parent company or acquirer must not enter into a mutually beneficial transaction with the target company unless all gains are assigned to the latter.

\section{PARENT-SUBSIDIARY MERGERS AND THE DIVISION OF GAINS}

Parent-subsidiary mergers should generally follow the same rules regarding the sharing of synergies as outright self-dealing. ${ }^{191}$ Where systematic differences exist, the parent company could arbitrarily exploit them by always choosing the

\footnotetext{
${ }^{188}$ Easterbrook and Fischel, n 12 above, 719. Javaras, n 40 above; Jennings, n 15 above, 47.

189 Meaning that each bidder's PBCs are set at a fixed percentage of his CFs.

${ }^{190}$ Clark, n 40 above, $\$ 11.3$.

191 Grossman and Hart, n 87 above, 195.
} 
mechanisms allocating the bigger share of the gain to itself, as both mechanisms have the common result of transferring assets between the two entities. ${ }^{192}$ Looking at parent-subsidiary mergers can therefore show whether all types of synergy gains are shared in the same manner in parent-subsidiary transactions.

US

In the US, the question of how to divide synergies between in a parent-subsidiary merger cannot be answered clearly. ${ }^{193}$ Although it is clear that shareholders are entitled to the pre-merger value of their shares, ${ }^{194}$ there is surprisingly little guidance beyond that.

In Delaware, parent-subsidiary transactions are subject to an 'entire fairness test', 195 but this does not really help, as the question of what 'fairness' means remains unanswered. From the legal literature, Brudney and Chirelstein, for instance, suggest dividing synergies according to the size of the respective companies. ${ }^{196}$ They do so by analogy to a trustee holding multiple accounts, in which case they assume he has to create proportionate sharing. The appeal of this solution is evident - the alternatives are a 50:50-sharing rule, which obviously would be subject to criticism due to its arbitrary nature, and a 'real' arms' length rule. The latter would require 'simulating' a bargain between two unrelated parties, which is doctrinally convincing, but restates, rather than answers, the question. A share-by-size requirement, however, is equally arbitrary, and definitely falls far short of mirroring a bargain of unrelated parties. ${ }^{197}$

Others argue that there should be no sharing requirement at all, basically for the same reasons why the MBR is rejected. ${ }^{198}$ However, the fairness-test (which can partly be substituted by disinterested board approval) guarantees the minority that a transaction proceeds 'on terms similar to those that might be expected of a transaction between willing buyers and sellers'. ${ }^{199}$

On the empirical side, Slovin has shown significant abnormal returns for minority shareholders following the announcement of parent-subsidiary mergers, indicating that parents do share some of the gains, to an extent comparable to

\footnotetext{
192 See, also, Gilson and Gordon, n 79 above, regarding the equivalence of different PBC-extraction mechanisms.

${ }^{193}$ Clark, n 40 above, $\$ 11.3,473-474$.

${ }^{194}$ This is to say, no compulsory sharing; see Alcott v Hymann, 208 A.2d 501 (Del.1965), Allied Chemical and Dye Corp v Steel Tube Co 120 A.486 (Del.Ch.1923).

195 Z. Goshen, ‘The Efficiency of Controlling Corporate Self-Dealing: Theory Meets Reality' (2003) 91 California Law Review 393, 396-439.

196 V. Brudney and M. Chirelstein, 'Fair Shares in Corporate Mergers and Takeovers' (1974) 88 Harvard Law Review 297.

197 This would be equivalent to saying that an individual contracting with a third party would make his demands conditional upon the net-wealth of the third party.

198 Easterbrook and Fischel, n 12 above.

${ }^{199}$ Goshen, n 195 above, 403.
} 
third-party transactions. ${ }^{200}$ The results vary widely, however, with the two inner quartiles ranging between $5.8 \%$ and $23.5 \%$.

\section{Germany}

Similarly, no explicit legal rules exist in Germany. ${ }^{201}$ The prevalent view for sharefor-share mergers favours a share-exchange-ratio based on the relative standalone values; ${ }^{202}$ this leads, in effect, to the solution suggested by Brudney and Chirelstein. ${ }^{203}$ On the other hand, squeeze-outs are often argued not to require any synergy sharing, ${ }^{204}$ which obviously is inconsistent.

For self-dealing transactions, the German rules require a strict at-arms'-length test, looking at the market value of the goods exchanged. Referencing to the market value already shows that some sharing will typically be required, as this is the expected result of arm's-length-bargains.

\section{$U K$}

In the UK, transactions between the parent and the subsidiary are primarily 205 constrained by the listing rules regarding related-party-transactions. ${ }^{206}$ These rules require disinterested shareholder approval for most transactions between the parent and the subsidiary, effectively giving the minority the last say. ${ }^{207}$ An alternative remedy for minority shareholders, triggered by conduct constituting 'unfair prejudice' by the majority shareholder, ${ }^{208}$ has not proved to be very effective, in contrast. ${ }^{209}$ More importantly, the appraisal usually awarded to successful shareholders, ${ }^{210}$ does not properly address the problem described here. ${ }^{211}$

The disinterested shareholder approval-rule can be expected to lead to an atarm's-length bargain, provided that the minority shareholders are not entirely passive. The strong presence of institutional investors could play a role in this

\footnotetext{
200 M. Slovin, 'The Economics of Parent-Subsidiary Mergers: An Empirical Analysis' (1998) 49 Journal of Financial Economics 255, 265.

${ }^{201}$ M. Winner, Wert und Preis im Zivilrecht (Vienna: Springer, 2008) 443.

202 eg, M. Lutter and T. Drygala in M. Lutter (ed) Kommentar zum Umwandlungsgesetz. (Cologne: Otto Schmidt, 2004) \5 No 31; see the overview given by Winner, ibid, 453.

203 Brudney and Chirelstein, $\mathrm{n} 196$ above.

204 eg, U Hüffer, Kommentar zum Aktiengesetz (Munich: Beck, 7th ed, 2006) \$305 No 22; but see, also, the opposite view expressed by Winner, n 201 above, 443.

${ }^{205}$ For the role of corporate opportunities-regulation, see D. Kershaw, 'Lost in Translation: Corporate Opportunities in Comparative Perspective' (2005) 25 Oxford Journal of Legal Studies 603, comparing the UK rules to the allegedly more flexible US-regulation.

206 UKLA Listing Rules, LR.11.

207 See Goshen, n 195 above, for a detailed comparison of the different strategies used to restrict selfdealing. LR.11 goes far beyond the general concept of self-dealing in the CA 2006: see Davies, n 13 above, ch 16-55.

208 s 994 CA 2006.

${ }^{209}$ Goshen, n 195 above, 430; Jennings, n 15 above, 43.

${ }^{210}$ Davies, n 13 above, ch 20-18.

${ }^{211}$ Clark, n 40 above, $\$ 12.2,508$.
} 
regard. ${ }^{212}$ Moreover, where creditors are affected, they also can enforce the arm'slength standard. 213

\section{Transferring gains}

Apart from these legal uncertainties, some synergy gains are hard to transfer under any legal regime. Turning back to Example 1 from above, it would probably be very hard to argue that $B$, after taking control of $S$, first rents $S$ 's land for 100 , and then sub-lets it to the football club for 150. Minority shareholders would probably not have great difficulties to show in court that this is 'unfair'.

This, however, would equal the transaction B2 has in mind. By only making all shareholders as well off as they are now, he is not sharing any of the gains he creates. At the same time, minority shareholders will have a hard time showing that a contract at the same terms as formerly concluded with an unrelated third party is unfair to them.

Similarly, synergies founded in the better management capabilities of the acquirer are also hard to transfer to the parent company. Such a transfer would require the new manager to receive all of the gains he produces as compensation for his services; independent directors would probably have a hard time justifying such a contract. 214

\section{Summary}

Sharing of gains does not seem to be explicitly addressed in the regulation of parent-subsidiary regulation. Some gains are hard to transfer between two companies without the threat of legal action.

Most legal systems probably provide some kind of assurance to the subsidiary's minority shareholders which requires the parent company to bargain 'at-arm's-length'. This means, however, that gains derived from different transactions will result in different allocations of gains, just as in the market place. The arm'slength-requirement common to most legal systems also means that the less comparable a certain type of transaction is, the greater the bandwidth of possible transactions. It is clear, however, that none of the rules described above even comes close to a mandatory 'target gets all' distribution of synergies. This is hardly surprising, as such a rule would offer less incentive to create such gains in the first place. $^{215}$

\footnotetext{
212 Goshen, n 195 above, 429.

213 D. Kershaw, 'Involuntary Creditors and the Case for Accounting-Based Distribution Regulation' (2009) Journal of Business Law 140, 155.

${ }^{214}$ But see R.S. Thomas, 'Explaining the International CEO Pay Gap: Board Capture or Market Driven?' (2004) 57 Vanderbilt Law Review 1171, 1200, who suggests that managers can capture all additional benefits (within the marginal revenue product-theory).

215 Some incentives would still exist, however, as the acquirer still indirectly benefits from the gains assigned to the target company in his capacity as the target's main shareholder.
} 
For the analysis provided here, this means that even (or: especially) ${ }^{216}$ in countries with high investor protection, the division of gains between a parent and a subsidiary depends on various external factors, including the transferability of gains, the existence of a market for comparable transactions, and the division of gains between unrelated parties in this market. Since synergy gains do not have to be assigned exclusively to the target company and the parent company (or the acquirer) may keep some of the gains, this also means that they, in fact, are PBCs as argued above.

This analysis is certainly not complete; it shows, however, that the same level of overall gains can lead to substantially different distributional results. As showed above, such differences can have implications for allocative efficiency.

\section{CAN THE MARKET RESOLVE THE PROBLEM?}

As showed above, the MR allows more efficient control transfers to happen than the MBR; on the other hand, it also allows some inefficient transfers, which are blocked under the MBR. ${ }^{217}$ In addition, the MR creates second-best outcomes in some private auctions of control-blocks, by failing to favour the most efficient bidder in taking control. The MBR, in contrast, does have such an efficiencyscreening function and leads to the best (or, sometimes inefficiently, none) of the bidders gaining control.

A possible objection to this analysis could assert that the bidder able to create the highest overall welfare gain (B1) will nevertheless be able to bargain with the other parties to achieve this goal. Two scenarios are possible to achieve that. First, B1 and the non-controlling shareholders could compensate the B2 for withdrawing his offer, therefore letting the best-bidder's offer prevail.

Depending on the value the control block has for $S$, the $B 1$ will often even be able to achieve that on his own, where he has some spare resources arising from differences in $P_{\min (\mathrm{S})}$ and $P_{\max (\mathrm{B} 1)}$. In effect, this would be a simple re-allocation of the purchase price by the most efficient bidder; instead of offering $P_{\max (\mathrm{B} 1)}$ to $S,{ }^{218}$ he could allocate part of the difference between his highest price and the $S$ 's reservation value to $B 2$ as a consideration for leaving the auction. ${ }^{219}$ Similarly, the minority shareholder could contribute their part of $C F_{\mathrm{B} 1}-C F_{\mathrm{B} 2}$ to the bribe.

\footnotetext{
216 Arguably, in countries with only minimal investor protection, the parent would extract gains up to the point that can be equated to stealing. Therefore, the distribution key would always be 100:0, which removes the differences between the efficiency and the transfer conditions.

217 This is in line with prior analyses; eg, Easterbrook and Fischel, n 12 above; Bebchuk, n 28 above; Bergström, Högfeldt, and Molin, n 53 above.

218 This would be the 'last bid' of B2 in an auction against B1.

219 Assuming the legality of such an agreement; the agreement described here is but a form of anticompetitive 'bid-rigging' (see M. Pesendorfer, 'A Study of Collusion in First-Price Auctions' (2000) 67 The Review of Economic Studies 381, who describes this behaviour in another context). Within the EU, this could be contrary to Art 81 (1) EC Treaty (see the wide definition in the Guidelines on the Effect on Trade Concept Contained in Articles 81 and 82 of the Treaty, OJ 27.4.2004, C 101/7).
} 
This would be an application of the famous Coase-theorem, 220 summarised in its 'strong version' by Zerbe as follows: 'In a world of zero transaction costs, the allocation of resources will be efficient, and invariant with respect to legal rules of liability, income effects aside. ${ }^{221}$

The ability to post a bid in the control auction, however, is analogous to what is referred to as a right assigned to an 'open class' in the context of the Coase's invariance hypothesis;222 the new bidder does not have to buy his right to participate in the auction. As Holderness showed, however, the Coase-theorem in its strong version only applies to rights assigned to a 'closed class'.223 Therefore, even without taking transaction costs into account, bargaining between the indeterminate group of bidders cannot always solve the problems.

In other words, $B 1$ and the non-controlling shareholders might often be unwilling to pay a 'bribe' to $B 2$ for leaving the auction, as $S$ will probably try to reopen the auction in order to reap a higher price. As $B 1$ 's maximum price for $S$ 's control-block is 'handicapped' by the fact that he generates a relatively large portion of the efficiency gains through a high $\triangle C F, S$ might be able to find yet another bidder $\left(B_{n}\right)$ with a higher reservation price for the shares than $B 1$ 's postbribe price. Naturally, $B 1$ and the non-controlling shareholders will not be able to pay 'bribes' to every potential new bidder. Being aware of this problem, $B 1$ will not even try to bribe $B 2$ in the first place.

Another question is whether bargaining between all shareholders (including $S)$ and $B 1$ will lead to him, rather than $B 2$ taking control. ${ }^{224}$ Applying the Coasetheorem, the answer is clear: in the absence of transaction costs, yes. The bargain would look as follows:225 $B 1$ pays his reservation price for the whole company $\left(V_{B 1}\right) ; 226$ and the non-controlling shareholders then bargain for a distribution of this sum, which by definition can always lead to a Pareto-improvement as compared with the current situation; $S$, therefore gets a price higher than $P_{\min (S)}$, while the non-controlling members get a price higher than their $S V_{N o n C}=$ $\phi_{\text {NonC }} \times C F_{S}$. With this kind of bargaining, therefore, it is unsurprisingly always

220 R. Coase, 'The Federal Communications Commission' (1959) 2 Journal of Law \& Economics 1 and 'The Problem of Social Cost' (1960) 3 The journal of Law and Economics 1.

221 The strong version of the Coase-thorem includes the so-called 'invariance hypothesis', not only predicting efficient but also the same outcomes, irrespective of the legal rules. See Zerbe, n 137 above, 4-5.

222 Open and closed classes in the context of the 'strong' (ie, invariance) version of the Coase-theorem were first discussed by C.G. Holderness, 'The Assignment of Rights, Entry Effects, and the Allocation of Resources' (1989) 18 The Journal of Legal Studies 181.

223 ibid, 187. S. Medema and O. Zerbe, 'The Coase Theorem' in B. Bouckaert and G. De Geest (eds), Encyclopedia of Law and Economics (Cheltenham: Edward Elgar, 2000) 843, argue that 'open class'-cases are actually already implicitly excluded by the requirement of defined property rights.

224 Note that we are now concerned with the allocation of the shares as a whole, rather than with simply submitting a bid.

225 Alternative solutions, such as a buy-out offer by $S$ before selling to B1 (Bebchuk, n 28 above, 966-967) differ only in form, not in substance, from the model described here.

$226 \mathrm{Or}$, indeed, any price exceeding the current value of the company $\left(V_{S}\right)$; the result is indifferent from an efficiency point of view, as any price between these two values leads to the same allocation result. Differences exist, of course, regarding the distribution of the gains. 
the most efficient bidder who wins the auction, as $B 1$ 's payment can always be allocated as among $\mathrm{S}$ and the non-controlling shareholders in a way superior to any other bidder's maximum payment. ${ }^{227}$

However, this kind of bargaining is unlikely to happen for various reasons. First, negotiations with (or among) a widely-dispersed shareholder body are costly per se; second, free-rider problems could obstruct the negotiations. ${ }^{228}$ Furthermore, part of the PBCs $S$ currently enjoys will sometimes involve some sort of illicit conduct on the part of $S$; hence, $S$ will not be able to use these parts of his current share value as a bargaining-chip in the negotiations with his fellow shareholders, without risking to be deprived of the corresponding values without consideration by court action. All of these reasons constitute 'transaction costs' in the sense of the Coase-theorem; they will normally prevent reaching a win-win compromise. ${ }^{229}$

Consequently, it is not possible to rely on bargaining between the shareholders in an MR-environment to achieve the same 'first-best' results realised by the MBR in the described situations.

\section{PRIVATE SALES AND PARTIAL BIDS}

A final remark relates to seemingly similar findings for tender offers in BerleMeans-companies. 230 In this context, it is suggested that decision-making problems sometimes lead to a less efficient bidder taking control, if partial bids are allowed. Similar to the situation described here, where shareholders are confronted with two offers, one partial by B2, and one full bid by $B 1$ (which is superior), they might sometimes accept the higher (but overall inferior) partial bid, due to collective action problems. ${ }^{231}$

Grossman and Hart use that to model the optimal voting structure for a company's stock. ${ }^{232}$ Although the problems identified in this work are similar in so far as one bidder (B2) will be able to 'offer more' due to higher PBCs, it is important to note the differences, too. In tender offers for widely-dispersed companies these inefficiencies only happen if, and to the extent that, shareholders expect other shareholders to tender into the lower full bid, therefore leaving them with a higher proportion of the purchase price from the partial bid (as it will not be pro-rated). ${ }^{233}$ In real-life situations, however, this is unlikely to happen. In Grossman and Hart's variant, the model assumes that shareholders tender into one offer, while expecting the other bidder to take control;234 this will rarely be the

\footnotetext{
227 Unsurprisingly, as the amount to be distributed is, in effect $V_{B 1}$. Ex hypothesi, $\mathrm{V}_{B 1}$ is higher than any other $V_{B n}$. B1 simply wins as the 'cake is the biggest' in negotiations with him.

${ }^{228}$ See, eg, Bebchuk, n 28 above, 966-967. See, also, Bebchuk, n 9 above, for an alternative way to tackle the collective action problems.

${ }^{229}$ Some attempts to facilitate a negotiation between target shareholders and B1 in order to allow efficient transactions otherwise blocked by the MBR can be seen in the 'whitewash-rules' of the City Code.

${ }^{230}$ Bergström, Högfeldt, and Molin, n 53 above; Grossman and Hart, n 9 above.

231 ibid.

232 ibid.

233 Grossman and Hart, n 87 above, 191.

234 ibid.
} 
case, as B2 will make his offer conditional on receiving the majority of votes. Similarly, B1 will only purchase the shares, where he receives enough shares to control the company; this might alleviate the problem.

Furthermore, it has to be borne in mind that the same logic would apply, where one person (eg the manager) submits a bid for, say, $0.5 \%$ of the shares at an enormously high price. In the Grossman and Hart model, ${ }^{235}$ all shareholders would, again, try to place their shares with this offer, and so every other bid could be eliminated at relatively small costs. It is doubtful whether the decision-making dilemma of the shareholders indeed reaches that far.

\section{CONCLUSION}

Building on prior work in this area, this paper analyses the efficiency of the mandatory bid rule and the market rule, respectively. It is suggested that the importance of synergies - commonly accepted as a main driver of takeover activity - needs to be re-emphasised. This is done here by explicitly including synergies into the notion of private benefits and accepting that they might be an important factor distinguishing bidders in any given legal system; this also calls into question common methods of using block premia in control transactions as a proxy for less-than-perfect investor protection rules.

It is further argued that the mandatory bid rule prevents some inefficient transactions from happening, where the bidder cannot easily be classified as a 'looter'. Anti-theft rules are therefore no adequate substitute for a mandatory bid rule in all circumstances.

Finally, it is shown that the mandatory bid rule offers some additional advantages over a purely deregulatory approach in auction-like private sales-ofcontrol; these, likewise, cannot easily be substituted by investor protectionregulation. On the contrary, where synergies are the only source of private benefits, the mandatory bid rule might be seen as fulfilling this 'efficiency screening'-function at relatively low cost.

It is sometimes argued that the mandatory bid rule is desirable from a fairness or equality point of view, and that this might outweigh some of its apparent efficiency disadvantages. Javaras, however, warns that 'equality' can only be justified if it somehow improves the functioning of the securities market'. 236

Although the analysis in this paper certainly does not cover all aspects of the related questions, and still more work needs to be done, the results presented here suggest that the mandatory bid rule might be more likely to pass this test than is commonly assumed.

235 See, also, Bergström, Högfeldt, and Molin, n 53 above.

236 Javaras, n 40 above, 428 . 